\title{
From Competition to Regulation: New Zealand telecommunications sector performance 1987-2007
}

July 2008

Bronwyn Howell

Paper to be presented at the International Telecommunications Society European Region Conference, LUISS Guido Carli University, Rome, Italy, September 17-20, 2008

New Zealand Institute for the Study of Competition and Regulation Inc. and Victoria Management School, Victoria University of Wellington, PO Box 600, Wellington, New Zealand. Email bronwyn.howell@vuw.ac.nz

Acknowledgement: The author wishes to acknowledge the helpful comments of Glenn Boyle, Roderick Deane, Lewis Evans, Heikki Hämmäinen and Bryce Wilkinson, and academic support from colleagues at the New Zealand Institute for the Study of Competition and Regulation, Victoria Management School, Victoria University of Wellington and the Networking Laboratory of the Helsinki University of Technology, during the preparation of this paper. Financial support was provided by the Deane Endowment Trust. The views in this paper solely reflect those of the author, and do not necessarily represent those of the institutions with which she is affiliated or their constituent members. Any errors or omissions remain the responsibility of the author. 


\section{Abstract}

Using an efficiency-based framework, this paper analyses the performance of New Zealand's telecommunications sector under competition law-based sector governance (the period from 1987 to 2001) and under industry-specific regulation (2001 to 2007). The framework considers the productive, allocative and dynamic efficiency effects of each regime, and the nature of the strategic interaction of sector participants.

The analysis reveals that substantial gains in all forms of efficiency were achieved during the 1990s, both compared to historic New Zealand and contemporary OECD benchmarks. Under industry-specific regulation, however, transfers to consumers appear to have reduced, transaction costs have increased and delays are being incurred in the deployment of new applications and technologies relative to the competition law regime as participants engage in strategic gaming with politicians and the regulator and respond predictably to the range of incentives offered under the regulatory regime. The paper concludes that on balance in the New Zealand circumstances, the regime based predominantly upon competition law appears to have outperformed the industry-specific regulatory regime, albeit due in large part to sector participant interaction shaped by contractual obligations imposed by the government on the incumbent which have prevailed unchanged under both regimes. 


\section{Introduction}

New Zealand was the first country in the OECD to adopt a 'light-handed' approach to telecommunications regulation when, in 1987, it eschewed industry-specific regulation, "relying instead on the potential for entry to discipline behaviour within the context of a business environment for which the competitive practices of all firms are subject to a single Commerce Act” (Boles de Boer \& Evans, 1996:24). The Telecommunications Act 1987 marked the end of combined state sector ownership and political control of the telecommunications sector that had characterised the New Zealand industry's first hundred years (Wilson, 1994). The reforms resulted in the removal of all regulatory restrictions on the supply of telecommunications equipment from mid 1988, the creation of a stand-alone telecommunications State-Owned Enterprise (SOE) on 1 April 1989, and the simultaneous removal of all statutory monopoly provisions protecting the state-owned enterprise from competition in any of its service provision 0activities (Howell, 2007).

The 'light-handed' regulatory environment established under the Commerce Act 1986 and the Telecommunications Act 1987 prevailed throughout the 1990s, during the privatisation of the incumbent provider (Telecom Corporation of New Zealand Limited, hereafter Telecom) in 1990, the entry of competitive fixed-line infrastructure and services suppliers from 1991, the establishment and growth of mobile market competition from 1994, the expansion of the commercial internet from 1996 and the consequent emergence of the 'information economy' (Howell \& Obren, 2003).

Contemporaneously, New Zealand emerged as one of the earliest-adopting and highestutilising OECD countries in respect of most of the demand-side indicators typically used to assess improved economic performance arising from the Internet, such as the number of individuals connected, the number of hours spent online, the number of secure servers per capita, the number of transactions per secure server and the number and use of autonomous and routed IP addresses per capita (Howell \& Marriott, 2004; Howell, 2006; 2007). Nonetheless, the country's broadband uptake has been low by OECD standards (Howell, 2003; 2006).

Since 2000, however, there has been a sea-change in the New Zealand approach to telecommunications regulation. Following a Ministerial Inquiry into the industry in $2000^{1}$, a

\footnotetext{
${ }^{1}$ Ministerial Inquiry Into Telecommunications http://www.med.govt.nz/templates/StandardSummary_ 16318.aspx 
Telecommunications Commissioner was established in 2002 to oversee industry activity ${ }^{2}$, an inquiry was held in 2003 on the merits of unbundling the local loop ${ }^{3}$, limited bitstream access was granted in $2004^{4}$, full unbundling and the ability to undertake standard terms determinations were mandated in $2006^{5}$ and in 2007, the Telecommunications Minister announced his intention to instruct Telecom to operationally separate its network activities from its wholesale and retail activities ${ }^{6}$ and that he, rather than the Telecommunications Commissioner, would take the lead in overseeing the separation process ${ }^{7}$. Also in 2007, the Minister of Economic Development directly brokered a fixed-to-mobile termination agreement with the two mobile network operators after the Minister of Communications twice rejected the Commissioner's recommendations to regulate prices and terms in this market ${ }^{8}$.

The swing of New Zealand's regulatory pendulum from light-handed regulation relying predominantly upon competition law to increasingly more stringent industry-specific regulation and arguably even a return to political control of sector strategy (Howell, 2008a) implies that the light-handed competition law-based regime failed to deliver on its objectives. That the industry-specific regulation that replaced it has also rendered less than satisfactory performance is suggested by successively stronger regulatory and finally political intervention. This paper seeks to test these contentions by using empirical evidence to examine the absolute and comparative performance of the sector under each regime. The performance of New Zealand's telecommunications sector under the competition law regime in particular, relative to both the contemporaneous performance of industry-specific regulated industries in other OECD countries and the New Zealand industry-specific regime that replaced it offers important insights for other countries as they contemplate the removal of aspects of industry-specific regulation in favour of greater reliance upon competition law to govern sector interactions.

The paper proceeds as follows. In Section 1, a set of measurement criteria to assess sector performance are developed. Section 2 assesses the performance of the competition law-based regime against these criteria relative to both the initial New Zealand conditions and other OECD countries. In Section 3, the performance of the industry-specific regulatory regime is assessed. Section 4 summarises and concludes.

\footnotetext{
${ }^{2}$ Commerce Commission http://www.comcom.govt.nz/IndustryRegulation/Telecommunications/Overview.aspx

${ }^{3}$ http://www.comcom.govt.nz/IndustryRegulation/Telecommunications/Investigations/LocalLoopUnbundling/Overview.aspx

${ }^{4}$ http://www.comcom.govt.nz/IndustryRegulation/Telecommunications/Investigations/Unbundling-

BitstreamServices/correspondenceandrelateddocuments.aspx

${ }_{5}^{5}$ http://www.med.govt.nz/templates/ContentTopicSummary_20266.aspx

${ }^{6}$ http://www.med.govt.nz/templates/ContentTopicSummary_26310.aspx

7 http://www.beehive.govt.nz/ViewDocument.aspx?DocumentID $=29595$

${ }^{8}$ http://www.beehive.govt.nz/ViewDocument.aspx? DocumentID $=29126$
} 


\section{Developing a Performance Measurement Framework}

Consistent with any performance assessment exercise, performance measures and benchmarks must be defined. From an economist's perspective, the appropriate measure to use is economic efficiency (total welfare) - the sum of consumer and producer surplus (Carlton \& Perloff, 2005:682). The solitary justification for either the enactment and enforcement of competition law or the application of industry-specific regulation is that it leads to increases in efficiency. If total welfare increases (decreases) as a consequence of an intervention/regime relative to a base starting point or counterfactual, then the intervention/regime can be adjudged as more successful (less successful), relative to the benchmark against which the comparison was made.

\subsection{Market Share Does Not Accurately Measure Welfare Gains}

Competition law and its associated jurisprudence are based upon the premise that pursuit of competition is justified when such pursuit leads to increased efficiency - that is, efficiency is the 'end' objective and competition is just one of a number of means towards that end. When pursuit of competition is contraindicative to the pursuit of efficiency (for example, in some high fixed or sunk cost industries where too much competition may result in inefficiently low levels of investment), then if competition law is sufficiently inflexible or unable to give due weight to efficiency-related issues, industry-specific regulation may be able to deliver more efficient outcomes (Carlton and Picker, 2007; Howell, 2008a).

It is therefore insufficient to adjudge the performance of a market under either competition law or industry-specific regulation by competition metrics alone. Whilst the degree of competitiveness measured by market shares or the Herfindahl-Hirschman index (HHI), and the Likelihood of Entry (LET) and Small but Significant Non-transitory Increase in Price (SSNIP) tests commonly used to assess market performance ${ }^{9}$ provide information about market structure, they do not take account of the actual behaviour of the market participants in response to the wide range of legal, regulatory and commercial obligations under which they interact. Neither do these criteria take account of underlying economic characteristics of the markets concerned that render the pursuit of less concentrated markets alone a poor proxy for the pursuit of either increased welfare or a realistic competitive process (Alleman \& Rappoport, 2005). For example, in markets characterised by high fixed and sunk costs, more intense price competition has been shown to result in a smaller number of firms at equilibrium

\footnotetext{
9 For example, in as prevails in New Zealand's Mergers and Acquisitions process - see http://www.comcom.govt.nz/Publications/ContentFiles/Documents/MergersandAcquisitionsGuidelines.PDF
} 
than either less intense competition or perfect collusion (Ford, Koutsky \& Spiwak, 2007:349$50)$.

\subsection{Prices Best Capture (Static) Consumer Welfare}

Rather, in order to derive a reliable view of the efficiency-related outcomes of the ensuing market interactions, the information about market structure derived from market shares, HHI, LET and SSNIP calculations must be assessed alongside other information that captures behavioural characteristics arising from responses to the incentives offered by the sector's specific contractual and institutional design. For example, in competition law regimes, the risks and penalties arising from likely prosecution for exertion of a dominant position may induce a dominant firm to charge prices close to the competitive level, even though it faces little actual competition. Furthermore, fringe competitors can impose disciplines upon prices charged by dominant firms (Carlton \& Perloff, 2005:110-119) which may not be accurately reflected in structural assessments alone, and where the gains accrued may be achieved more cost-effectively than from ex ante regulatory provisions requiring extensive and costly monitoring and enforcement. Therefore, regardless of any assessment of the presence of market power, prices in a market arguably offer a superior assessment of actual market performance. Specifically, they directly reflect the welfare of consumers arising from actual sector interactions and therefore provide a more accurate barometer of welfare gains than market concentration measures (Hausman \& Sidak, 2007).

Comparative performance can be assessed using benchmarked prices between markets or in one market across time. Furthermore, benchmarked comparisons of actual market performance are more realistic than comparisons of a single market benchmarked against a selected theoretical ideal (e.g. 'perfectly competitive' TELRIC or TSLRIC prices) which is rarely if ever evidenced in practice. For example, Hausman and Sidak (2007) use benchmarked prices in one market in one country deemed competitive on the basis of structural parameters to illustrate that lower prices in the same market in another country that had been adjudged not sufficiently competitive on the basis of the same structural parameters was performing more efficiently and therefore better serving the long-term interests of its consumers than the supposedly more competitive market. Individual prices can be used for comparing individual markets, whilst price indices can be used to compare sector-wide performance over a much larger basket of products and services. The proportional changes recorded using indices also enable direct and relevant comparisons to be made between markets of very different size. 
In telecommunications markets, the number of connections has been widely used as a proxy measure of consumer welfare, as it is presumed that as prices decrease, the number of connections, and therefore consumer welfare, increases. In a mature market constrained by exertion of market power, prices will be higher than efficient and the number of connections will be lower than efficient. In such circumstances, connection numbers in have been used to proxy consumer welfare changes in regulated markets, simply because changes in connection numbers are easier to capture and compare as a measure of change in consumer welfare actually derived than more volatile pricing data (Melody, 2005). However, in markets for emerging products, connection numbers are a less reliable proxy for consumer welfare conferred, as many factors other than price or exertion of market power may affect the rate of purchase (e.g. wealth effects, availability of applications, information asymmetries, varying customer valuations - Howell, 2008). For the purposes of this paper, connection numbers will not be used as a primary measure of performance, except where they either confirm or defy price-based analyses or suggest that other anomalies in market performance may exist.

As with the number of connections, levels of usage (e.g. voice minutes, megabytes downloaded) are also typically a function of price, with low prices leading to higher usage and thus the accrual of higher levels of consumer welfare. Normally, changes in usage prices are sufficient to imply changes in consumer welfare. However, measuring usage levels becomes important in capturing consumer welfare when that usage is effectively unpriced (e.g. in the case of 'flat rate' tariffs, where usage is subsidised from connection charges, and heavy users are effectively subsidised by light users). For the purposes of this paper, given the obligations upon the main provider to supply 'flat rate' local voice telephony services and the common use of flat rate pricing for internet connections, usage will be used to further assist in the assessment of consumer welfare accrued.

\section{$1.3 \quad$ Revenues, Producer Surplus, and Price Benchmarking}

Producer surplus is typically measured as revenue less the costs of production and the opportunity cost capital. A producer with market power charging prices in excess of the costs of production and capital will thus accrue higher revenues for a given volume of output than one with equivalent costs charging the 'efficient' cost-based price. Thus, just as with price benchmarking, revenue benchmarking against a presumed 'competitive' revenue level can be used to assess the likely extent of prices being charged in excess of cost. If observed revenues are higher than the benchmark revenues, then higher profits are being made in the observed market than in the benchmark one - producer surplus is higher. 
However, producer surplus has to be considered in conjunction with the level of consumer surplus (assessed from prices and/or quantities) to make an assessment of overall welfare levels. If both revenues and prices are higher than the benchmark levels, then there is a transfer of welfare from consumers to producers, and it is likely the observed market is operating less efficiently (i.e. at lower levels of consumption) than the benchmarked one. Higher prices and lower revenues are consistent with lower levels of consumer welfare due to low usage as would be indicated by high prices alone. By contrast, lower prices and higher revenues suggest lower-cost production and higher utilisation, but not any apparently greater exertion of market power. Simply, consumer welfare is higher due to higher usage at the lower prices. Lower prices and lower revenues may occur if there are more extensive supply constraints, which can be cross-checked against utilisation evidence. If utilisation is higher, then lower prices and lower revenues might indicate a market where welfare accrued is allocated predominantly to consumers rather than producers (for example, where price controls or other regulation limits the extent to which producers can share in the market proceeds).

\subsection{Dynamic Efficiency: Investment Levels, Timing and Entry Patterns}

Revenues, retail prices, the number of connections and usage provide an assessment only of the static component of efficiency. They do not take account of dynamic efficiency - the gains that come from product and process innovation. Whilst dynamic efficiency is notoriously difficult to measure, a range of factors can be used to assess performance in this dimension.

The level and timing of investment in both existing and new infrastructures are key measures. In principle, if the correct incentives are in place, new and/or cheaper technologies will be introduced in a timely manner, leading to increases in welfare from both increased consumer surplus from more highly-valued or lower-priced products, and increased producer surplus from either reduced costs or new profit-making opportunities (Hausman \& Sidak, 2005:183). New technologies, however, require investments to be made, which will be captured in records of investment levels. Where absence of competition reduces the need for a firm to invest in new technologies, then new, consumer welfare-enhancing investments can be deferred, especially if there are hard-to-assess risks associated with the investment. Total investments are likely therefore to be less than in the competitive case, and the time at which new technologies are made available to consumers will be delayed (Guthrie, 2006). Where competition is geographically uneven, a provider with market power may choose only to invest in the new technologies in areas where competition exists, limiting the total investment 
made and the size of the customer pool that can purchase the new products and services. Once again, benchmarking against a comparator across the extent of the possible consumer market enables relative performance assessments to be made.

High levels of market concentration are associated with lower levels of dynamic efficiency due to presumed reduction in rivalry between the firms concerned. However, absence of actual competition on its own is insufficient for a finding of low levels of dynamic efficiency gains without examining the wider regulatory environment. If entry barriers are low, then the simple threat of entry may be sufficient to induce earlier commitment and higher levels of investment than if such entry was not likely (e.g. if restricted by the need to first acquire a licence).

\subsection{Transaction Costs and Regime Efficiency}

Whilst static and dynamic efficiency measures captured in prices, revenues, connection, usage, investment levels and investment timing measure sector performance at the operational level, overall sector efficiency must take into account the total costs creating, monitoring and enforcing the legal and institutional framework in which the sector operates. This includes the court processes for competition law-governed regimes, and the operation of the regulatory bodies under industry-specific regulation (Evans \& Quigley, 2000). The costs may be both tangible, in respect of the costs actually expended, which affect static efficiency, and intangible in respect of prospective gains foregone, a dynamic efficiency measure. For example, some regulatory obligations such as local loop unbundling have been implicated in delays in investing in new technologies, with consequent reductions in the ability of consumers to accrue the gains from using superior technologies (Hausman \& Sidak, 2005).

\subsection{Selecting the Benchmarks for Assessing New Zealand's Performance}

A comprehensive comparative assessment of the performance of New Zealand's regimes must therefore be based upon a comprehensive set of measures of static and dynamic efficiency, covering the prices, revenues, connection rates, usage levels, investment levels, investment timing and institutional governance costs. Whilst clearly, the relative performance of the industry-specific regulatory regime can be benchmarked to that of the competition lawgoverned regime, it is possible to benchmark both against the same metrics from other regimes. 
For the purposes of this paper, given the interest that New Zealand's competition lawgoverned regime has engendered as the first in the world to eschew industry-specific regulation, its performance will be benchmarked against performance metrics over the same period of other selected OECD countries and the OECD average. Whilst it is recognised that the OECD average is an amalgamation of many different regimes, the common factor linking all other countries is that their telecommunications markets were governed primarily by industry-specific regulation.

If on balance over all of the chosen metrics the New Zealand competition law-based regime can be shown to be operating less efficiently than the average OECD country over the period 1987-2001, then it can be concluded that the introduction of industry-specific regulation in 2001 might be justified in the pursuit of increasing the efficiency of the New Zealand telecommunications sector ${ }^{10}$. If, however, it is found to be operating more efficiently than the average OECD country, then the introduction of industry-specific regulation of the form promulgated as 'best practice' by the OECD and applying over the period 2002-2007 might be expected to result in reductions in efficiency relative to the New Zealand competition lawbased benchmark. If the latter is shown to be the case, then increasingly stronger industryspecific regulatory intervention is unlikely to lead to increased efficiency - indeed, such actions would likely be associated with further declines in the performance of the key metrics observed.

\section{The Competition Law-Governed Period 1987-2001}

New Zealand's 'light-handed' telecommunications regime based upon the Commerce Act 1986, precluding the exertion of a dominant position (Section 36), and the Telecommunications Act 1987, was predicated upon a government policy of pursuing economic efficiency (in all of its productive, allocative and dynamic dimensions) and "achieving, wherever possible, a competitive environment in which markets can operate relatively free from subsequent government involvement” (Evans, Grimes, Wilkinson \& Teece, 1996:1863). Industry-specific regulation was eschewed in part due to its high fixed costs in relation to the very small size of the New Zealand market (only 4 million citizens) and the view that "across the world, this style of regulation has proven itself to be inflexible,

\footnotetext{
${ }^{10}$ It is noted that the 2000 Inquiry that recommended the introduction of industry-specific regulation took as its performance benchmark for the sector that of perfect static efficiency. As the prices charged by the incumbent were deemed not to be perfectly competitive prices, intervention was recommended. However, in respect of dynamic efficiency, regulation of newer services (e.g. ADSL) were nor recommended to be subject to regulation (Howell, 2007 interpreting the Ministerial Inquiry into Telecommunications report http://www.med.govt.nz/templates/StandardSummary_16318.aspx
} 
overly bureaucratic and very costly to administer” (Blanchard, 1995:474) - that is, transaction cost-intensive.

The use of competition law in New Zealand as the primary means of governing interactions in network and infrastructure industries such as telecommunications, electricity, railways and airways was consistent with its use across all other industries in the small economy, given the very high concentration levels observed overall in New Zealand as firms moved wherever possible to take advantage of horizontal and vertical scale and scope economies. Arnold, Boles de Boer \& Evans (2004) observe three firm concentration ratios exceed $90 \%$ in nearly all of New Zealand's significant industry sectors, with many (e.g. supermarkets) having only two significant firms.

\subsection{A 'Lightly-regulated' but not 'Unregulated' Sector}

The Telecommunications Act 1987 removed all entry barriers in the provision of both services and equipment from the New Zealand market ${ }^{11}$. However, contrary to assertions that competition law alone governed sector activities (e.g. Spiller \& Cardilli, 1997), the Commerce Act (Part IV) contained provisions for Ministerially-imposed price control in the event of repeated transgressions of Section 36 by firms with a dominant position, and the Telecommunications Act imposed reporting obligations upon the incumbent provider Telecom. Furthermore, when Telecom was privatised in 1990, the new owners entered into an agreement with the government, known initially as the 'Kiwi Share' and from 2001 the Telecommunications Service Order (TSO).

Under the 'Kiwi Share', Telecom was bound to guarantee that the price of residential telephone rentals would not rise faster than the Consumer Price Index (CPI) unless profits were unreasonably impaired (the 'price cap' obligation), rural residential rental prices would not exceed urban residential rentals (the 'universal service' obligation) and residential customers would continue to be offered a tariff with no charges for local calls (the 'free local calling' obligation) ${ }^{12}$. These obligations preserved New Zealand's long history of wealth transfers between consumers via universal service prices and free local calling prevailing since 1880 (Howell, 2007; Wilson, 1994), and ensured that New Zealand's 'free local calling' zones, amongst the most extensive in the OECD (NZIER, 2005), remained intact in the privatised, deregulated environment.

\footnotetext{
${ }^{11}$ It is one of the very few countries where no licence is required to operate (Lim \& Chen, 2008)

${ }^{12}$ Changes to prices (outside these guidelines) or any of the the other terms, required the approval of the Minister of Communications.
} 
Competitive entry occurred rapidly in both the fixed and mobile markets. Clear Communications (subsequently TelstraClear) entered the fixed line market in $1991^{13}$, gaining market shares of $20 \%$ and $23 \%$ in the long-distance and international markets respectively in its first five years of operation (McTigue, 1998). Its impact on the local calling market was initially small, due in part to a protracted dispute with Telecom over local interconnection charging (the key part of the dispute being the legitimate charging method to use given Telecom's need to recover the costs of the 'Kiwi Share' social obligations - Howell, 2007:1720) ${ }^{14}$, but following the resolution of the case by the Privy Council in 1994 in favour of Telecom, and a Ministerial Review in 1995 confirming that the regulatory arrangements would not change (MoC/Treasury, 1995), entry activity increased. Telstra entered in November 1996, Saturn in June 1997 and Compass in September 1998 (Karel, 2003). Despite the extent of competitive entry of alternative service and infrastructure providers in the fixed line market (Howell \& Obren (2003) record 19 registered providers in 2003), with high uptake of lines in those areas where duplicate technologies were available (anecdotally up to $25 \%$ of homes in those areas passed by Saturn (subsequently TelstraClear), nationwide the number of lines sold by competitors remained small (less than $4 \%$ in 2003 - Howell \& Obren, 2003).

Mobile competitive entry occurred in 1994, when BellSouth first began selling services on its GSM network in competition to Telecom's TDMA and subsequently CDMA-based network services ${ }^{15}$. Whilst Telecom held an early market advantage, BellSouth (subsequently Vodafone) quickly developed a significant market presence, having approximately one third of the market by connections and slightly more by call minute volumes by the end of $2000^{16}$.

\footnotetext{
${ }^{13}$ Clear Corporation, held by majority owners MCI International and Bell Canada Enterprises, with minor partners New Zealand Railways, Television New Zealand, and Todd Corporation (Boles de Boer and Evans, 1996), entered the market using the then New Zealand Railways fixed fibre-optic cable to bypass the Telecom network. Clear invested in the provision of local infrastructures servicing the business districts in most New Zealand cities, as well as the domestic and international long-distance markets (Evans, Grimes, Wilkinson and Teece, 1996). In 1991, Saturn Communications was established on the Kapiti Coast, near Wellington, providing telephony and television services via fibre-optic cable. Telstra Corporation (Australia) established Telstra New Zealand in 1996. Telstra New Zealand purchased Saturn in 1999 and Clear in 2001, forming TelstraClear Ltd on December 152001 http://www.telstraclear.co.nz/companyinfo/history.cfm.

${ }^{14}$ The use by Telecom of the Efficient Component Pricing Rule (ECPR), which included a margin to recover the costs of providing social services, was deemed to be what a competitive firm would charge in the same circumstances. Moreover, Clear had failed to demonstrate that Telecom's prices were indeed in excess of costs, even including the component to recover social obligation costs.

${ }^{15}$ BellSouth started its GSM cellphone service in 1994 (Evans, Grimes, Wilkinson and Teece, 1996). Vodafone purchased BellSouth in November 1998, forming Vodafone New Zealand http://www.vodafone.co.nz/personal/about/company-information/ ${ }^{16}$ Data from ISCR Telecommunications Database derived from market shares reported by the firms in quarterly reports.
} 


\subsection{Prices and Static Efficiency in the Fixed Line Market}

Despite the apparent lack of competition in the fixed line market, the New Zealand residential price index for fixed line services over the period 1991 to 2001 (indexed to 1991 prices) (Figure 1) shows substantial decreases occurred in all of connection (to 90\% of 2001 levels in 2001), long distance (36\% of 1991 levels in 2001) and the bundle of combined line rental and calling charges (65\% of 1991 levels in 2001). This suggests that under the competition lawgoverned regime, residential consumers enjoyed substantial gains in welfare over the 1990s relative to the position in 1991 when Telecom was listed on the New Zealand stock exchange. Whilst clearly competition in long-distance calling was a significant factor in these prices falling, it is notable that fixed line rentals also fell in real terms, despite the very small amount of actual competition in the market nationwide in the fixed line rental market.

\subsubsection{Larger Relative Consumer Welfare Gains from PSTN Price Falls}

In practice, apart from small changes in 1992 and adjustments in the few areas where facilities-based entry occurred, Telecom's nominal prices charged for residential line rentals remained unchanged across the 1990s. Consequently, the real price fell steadily across the decade. The consistent nominal line rental charge prevailed in part because the 'price cap' Kiwi Share obligation made it difficult for the firm to raise this price without first seeking political approval. In addition, the sale of Telecom to initially predominantly American owners meant any price rises, even if within the agreed bounds, would attract political interest as a consequence of a populist perception of 'expropriation' of New Zealand resources by foreigners. Threat of political attention thereby offered an additional constraint upon the temptation for Telecom to exert its market power by raising prices.

Figure 2 shows the OECD Telephone Charge Time Series (indexed to 1990) up to 2007. Whilst the two indices are not strictly directly comparable due to the bundles being based upon different calling baskets, a sense of the extent of the welfare gains made by New Zealand consumers relative to the average OECD consumer over the 1990s can be discerned. Over approximately the same time period (the OECD time series is indexed to 1990), the average OECD line rental (largely comparable to the New Zealand line rental in Figure 1) rose to more than $120 \%$ of its 1990 level by 2001, whilst the bundle of line rental and calling (broadly comparable to the New Zealand residential telephone service in Figure 1) fell to around only $80 \%$ of its 1990 level by 2001 .

Comparative benchmarking thus suggests that the relative welfare gains to New Zealand residential consumers from lower prices over the period 1990-2001 were substantially greater 
than those accrued by the average OECD consumer of fixed line telephony services. A large proportion of the gains are likely due to New Zealand line rentals not being adjusted upwards, as occurred in most of the rest of the OECD over this period when the advent of competition led to the requirement in most other OECD countries that providers 'unbundle' (or 'rebalance') connection and calling charges, thereby removing the cross-subsidy from calling (both local and long-distance) to connections that had been implemented in part to increase the number of connections sold to price-sensitive residential consumers (Laffont \& Tirole, 2002). Despite the dominant position of the incumbent provider, threat of legal action over abuse of that dominance combined with the price cap obligation of the Kiwi Share and its associated political connotations appear to have resulted in a greater proportionate welfare gain for New Zealanders than delivered under industry-specific regulatory regimes in the rest of the OECD.

\subsubsection{Enhanced Gains From 'Free Local Calling'}

'Rebalancing' of line rentals and local call charges did not take place in the New Zealand residential market because the 'free local calling' obligation precluded Telecom from undertaking such an exercise (although rebalancing was undertaken in the business market, where line rentals were reduced and call charges introduced for the first time in 1992). Given the extensive local calling areas and zero-priced residential calls, New Zealand calling patterns differ substantially from countries where local call charging prevails (NZIER, 2005). Telecom management reports in 2003 recording the volumes of chargeable and unchargeable minutes on the PSTN indicate that only $20 \%$ of traffic in that year was able to be charged. By benchmarking chargeable minutes between Finland and New Zealand, Howell \& Sangekar (2008) find that New Zealand local calling volumes per line were around four times those observed in Finland, most likely as a consequence of the 'free local calling' obligation.

The advent of the internet as a significant commercial force had significant ramifications for the New Zealand fixed line telephony market, due to the 'free local calling' obligation and the initial use of dial-up modems as the predominant method of internet connection. Figure 3 shows the growth of internet traffic in New Zealand relative to other calling volumes. As the telephony component of internet calling was not charged, New Zealand dial-up internet use was extremely prolific compared to those countries where local call charging prevailed (OECD, 2000). New Zealand internet service providers (ISPs) were amongst the first to offer flat-rate charges for their services (Enright, 2000), leading to New Zealand rapidly becoming one of the most highly-connected and highest-using internet consumer markets in the OECD. Figure 4 shows that at the peak of dial-up usage in 2003, New Zealand's 850,000 dial-up 
internet users were consuming on average 35 hours per month (more than one hour per day) connected to their ISPs over the PSTN.

Unlike in countries where local call charging prevailed, none of the increased PSTN usage by residential consumers for internet connection generated any additional revenue for Telecom. Practically all of the PSTN usage servicing dial-up internet usage in New Zealand was accrued as consumer surplus. As the New Zealand price index in Figure 1 does not take account of the additional volumes of New Zealand internet usage relative of that in other OECD countries charging for the service, the extent of the welfare gains in terms of the actual price paid per minute of PSTN connectivity fell by a much greater extent in New Zealand than is reflected in the comparator OECD index. The extent of the consumer welfare gain by New Zealanders across the 1990s in respect of PSTN charging was therefore very much greater than that enjoyed by other OECD residents, due to 'free local calling' resulting in a higher level of consumption per user (i.e. the marginal dial-up internet user in New Zealand had a lower valuation per minute of usage than the average OECD user, as New Zealand users consumed to the point where marginal value of use was zero rather than to the point where the marginal value equalled the cost per minute of the call).

\subsubsection{Revenues Confirm Consumer Welfare Gains from Increased Usage}

The effect of 'free local calling' on Telecom revenues is evidenced in Figure 5, which benchmarks revenues in New Zealand, the OECD as an aggregate and selected comparator countries between 1991 and 2002, indexed to 1997 when dial-up internet use began to be a significant factor. Figure 5 shows that whilst New Zealand's revenues as a proportion of 1997 revenues tracked the OECD average between 1991 and 1997, after 1997, whilst OECD average revenues grew to $135 \%$ of their 1997 levels by 2002, New Zealand revenues remained static, exceeding 1997 levels in nominal terms only once in the period (2002) and then by only a very small margin. By contrast, Korean revenues grew to 250\% of 1997 levels and the United States to $140 \%$. Only Norway and the United Kingdom recorded revenue indexes lower than New Zealand over the entire period 1997 to 2002. Australia had revenues in excess of 1997 levels in all years except 2002.

Revenue figures thus confirm the presumption that not only did New Zealand exhibit much higher levels of internet use than the average OECD country over the 1990s, but that the gains from this additional use were appropriated almost totally by consumers. Producer gains from this increased use were non-existent.. The gain by New Zealand consumers relative to other OECD countries from the advent of the internet was therefore very much larger due to the charging arrangements prevailing. The combined arrangements of both competition law 
governance, and the specific provisions of New Zealand's 'light-handed' regulatory regime the 'price cap' and 'free local calling' obligations of the 'Kiwi Share' - thus appear to have delivered superior static efficiency gains in the form of increased consumer welfare than the ‘average’ OECD industry-specific regulatory arrangements.

\subsection{Dynamic Efficiency: Investment and New Technologies}

Despite the substantial static efficiency gains accrued, it might have been expected that Telecom's dominant position would result in it delaying investment in new technologies namely broadband services. The evidence, however, does not bear this out.

\subsubsection{Early, Widespread, Low-Priced and High Quality ADSL}

Rather than being a laggard, Telecom invested early and extensively in ADSL. When the first commercial ADSL services were offered in Wellington from January 1999, New Zealand became only the third OECD country after the United States and Canada to provide the technology. Nationwide rollout proceeded rapidly, with services available to $85 \%$ of consumers (by lines) by 2002 (extended to 94\% by 2007 (OECD, 2008:34) but due to geographic and technological constraints this is unlikely to be exceeded). Moreover, the base level product installed was a fast 2 Mbps service, with $128 \mathrm{kbps}$ and $256 \mathrm{kbps}$ products being installed only when firstly consumer preferences and secondly government purchasing requirements for subsidised rural connection programmes demanded them (Howell, 2003).

Whilst it might also have been expected that the monopoly provider would have levied high prices for the new (monopoly) service, the evidence confirms that this did not occur either. OECD (2001) price benchmarking showed that in 2001 the prices for the New Zealand ADSL products were $2^{\text {nd }}$ and $3^{\text {rd }}$ lowest in the OECD after price leader Korea OECD. New Zealand's low prices and comparatively high speed of services offered have continued across the 2000s. OECD (2008) benchmarking shows that in October 2007, New Zealand had the seventh lowest monthly subscription prices (Figure 1.14, p 42), the $7^{\text {th }}$-lowest prices per megabit second ${ }^{17}$ (Figure 1.15, p 43) and the $8^{\text {th }}$ fastest download speeds offered by an incumbent operator (Figure 1.16, p 44), despite being ranked only $20^{\text {th }}$ in the number of connections per capita in June 2007 (Figure 1.4, p 25).

Thus, in terms of both the timing and availability of new services, the arrangements in place during the 1990s do not appear to have hampered the supply side investment in and pricing of

\footnotetext{
${ }^{17}$ Prices are expressed in United States dollars, correcting for the purchasing power parity of each country.
} 
new technologies. The potential for dynamic efficiency gains appears to be on average greater in New Zealand than in the average OECD country. The apparently perplexing New Zealand enigma is why the demand side of the market, already one of the most extensively using dial-up internet countries, has failed to rapidly convert that extensive usage to broadband $^{18}$.

\subsection{2 'Kiwi Share' and Investment Incentives}

Whilst New Zealand's liberal entry provisions led to investment by multiple providers in multiple competing technologies (Ethernet LAN in 1995, satellite in 1998, cable in 1999, wireless in 2002 and mobile broadband in 2005 - Howell, 2007), each (except for satellite, which was available nationwide) offered only fringe competition to Telecom. Yet due to New Zealand's long history of universal service pricing, fringe competition has had a significant effect on prices in the market. Whilst there was no 'Kiwi Share' obligation to do so, Telecom offered ADSL services nationwide at the identical tariffs, independent of the different costs or differing extent of local competition. Whilst satellite was the early price leader, the prices for all of the technologies (when accounting for speed and other differentiating factors) have converged to very similar levels nationwide, irrespective of the provider identity or actual market presence (Howell, 2003).

The early introduction, low pricing and wide availability of ADSL are also due in large part to Telecom's ‘Kiwi Share' obligations. The interconnection agreement agreed in 1996 between Telecom and Clear, which became the prototype for all other network contracts, saw the network owner whose customer originated a call paying a termination charge to the operator on whose network the call terminated. With the emergence of the internet, as a consequence of 'free local calling', PSTN call minutes grew exponentially (Figure 3), creating an arbitrage opportunity for network operators who could sign up a disproportionate number of the ISPs as customers.

\subsubsection{Strategic Responses to Competitor Actions}

Telecom's competitors seized upon the arbitrage opportunity. Karel (2003) notes significant cash payments were made to ISPs to join rival networks, and these payments were shared further with consumers as discounted or even free ISP account fees. The result was a highly competitive ISP market, with low ISP charges and free PSTN access. Boles de Boer, Enright \& Evans (2000) note that New Zealand ISP charges were between 13\% and 30\% lower than Australian charges at the time, despite New Zealand having only one third of the number of

\footnotetext{
${ }^{18}$ See Howell $(2007 ;$ 2008b) for a full discussion.
} 
ISPs per capita. Whilst New Zealand concentration levels were higher, the extent of rivalry was very much greater, and consumer welfare correspondingly higher as the ISPs shared the interconnection gains with consumers. The combined low ISP and PSTN charging for internet use likely accounts for the very low New Zealand sector revenues (below even 1997 levels) in Figure 4 compared to other countries and the OECD average.

Because of the 'free local calling' obligation, and because the vast majority of internet calls originated on its network, Telecom faced huge losses from contractual arbitrage as the 'free local calling' obligation precluded it for charging for the internet calls. An average internet user signed up to a non Telecom-affiliated ISP in 1999 was generating an interconnect obligation for Telecom of $\$ 36$ for a monthly rental (including all local calls) of only $\$ 30$ (Howell, 2007). Due to the revenue-sharing incentives offered by Telecom's competitors, non-Telecom ISPs likely attracted a disproportionate share of the high volume users, meaning the interconnection losses to Telecom from the 50\% of ISP customers not served by its proprietary ISP Xtra likely substantially exceeded the average of \$6 per month per account.

Telecom's strategy to invest early in high-speed ADSL priced very cheaply was half of a twopronged strategy to avert the cash flows to competitors. If high-using dial-up internet users (who were causing most of the interconnect losses) could be induced to migrate early to new chargeable broadband connections, then losses could be averted. Indeed, if the dial-up telephony account could be tied to the ADSL account, then some of the notional 'savings' from the interconnection costs and PSTN internet calls averted could be shared with the consumer via an ADSL account where the connection was priced below cost, and the firm would still be in a stronger financial position than under the status quo. In order to induce even low-volume users to switch, Telecom sold ADSL connections under a variety of twopart tariffs, where connection and usage were charged separately (a charging policy adopted by all of the competing providers, even though they did not face the same interconnection and free local calling pressures) ${ }^{19}$.

Despite these inducements, initial ADSL uptake was sluggish, leading Telecom in September 1999 to impose a retail charge of 2c per minute (the termination charge) for internet calls made to non Telecom-affiliated ISPs for all calls made after ten free hours a month had been consumed (which still constituted an interconnect liability to Telecom of \$12 per month for every consumer calling a non-Telecom ISP - setting a bound on the notional loss that

\footnotetext{
19 In part due to the fact that over 95\% of New Zealand internet traffic comes from overseas over the monopoly Southern Cross Cable, which due to peering agreements sees New Zealand internet users paying all of the costs of both uploaded and downloaded traffic across this trans-Pacific cable.
} 
Telecom could incur on an ADSL connection and still be in no worse a position than under the status quo). This action, which became known as the '0867' case after the calling prefix of Telecom-affiliated ISPs, was approved by the Minister under the provisions of the 'Kiwi Share', but the Commerce Commission, responding to complaints by Telecom's competitors, laid a charge under Section 36 of the Commerce Act alleging that Telecom's action in instituting the charge constituted an anti-competitive exertion of its dominant position. The High Court ultimately decided that Telecom's actions did not constitute a breach of Section 36. The '0867' charges went ahead, the cash losses ceased, and the interconnection agreements ran their full length, being replaced in 2001 by a 'bill and keep’ agreement (Evans \& Quigley, 2000), and ultimately in 2002 by regulated rates under industry-specific regulation (Howell, 2007).

\subsection{Transaction Costs}

Whilst there were clearly superior gains for New Zealand consumers at the expense of Telecom over the 1990s as a consequence of the interaction of the competition law regime and the 'Kiwi Share' provisions, and with few apparent impediments to investments in new technologies, the question of the systemic transaction costs incurred in order to appropriate these gains must be considered. Only two cases alleging a breach of Telecom's dominant position were brought during the 1990s, and in neither case was it found that Telecom had transgressed. Nonetheless, criticisms were made about the process of bringing a case under Section 36. These centred around the time taken to resolve a court case, and the costs of such actions.

\subsubsection{Costs of Court Cases}

The 'Clear' case took three years and hearings in three courts (High Court, Court of Appeal and the Privy Council) to be resolved. The '0867' case brought in 1999, was finally adjudicated in 2008 - a span of nine years. Both involved substantial costs, in terms of expert evidence and the provision (in many cases the recreation) of key information regarding the actions undertaken by the various parties. Nonetheless, these costs constitute the sole out-ofpocket expenses incurred under the competition law-governed regime.

It is somewhat harder to quantify what opportunity costs might have been foregone as a consequence of the competition law regime. Whilst plausibly the absence of a regulatory regime requiring detailed reporting of prices, costs and other data may have made it harder for firms to adjudge the likelihood of Telecom's prices being anti-competitive when making the decision about whether to take a Section 36 case (Blanchard, 1994a; 1994b), ex post analysis 
of the form above suggests that the small number of cases observed may have been because few breaches were actually incurred. Moreover, if the court-based system is working efficiently, cases should only be brought if the likely gains (weighted by the probability of the result being favourable) exceed the costs of doing so.

\subsubsection{Court Processes and Dynamic Efficiency Gains from Entry}

It has also been suggested that firms may have delayed entering the market whilst awaiting the result of the court actions brought by another firm (MoC/Treasury, 1995). However, to bring a case, a contract must actually have struck (or in the case of '0867', a different product mix must be brought to market). Clear could still transact with customers on the basis of the initial interconnection agreement, even whilst it was under dispute. Some gains in welfare could therefore potentially accrue to consumers from product differentiation, albeit not as many as if all potential efficiency-raising entry occurred at the outset. Likewise, losses in welfare were averted by Telecom being able to proceed with the '0867' charges whilst the case was being resolved.

By contrast, under a regulated system, regulated services are typically not offered until the regulator and all firms concerned have agreed terms, precluding any potential offering of services to consumers and consequently delaying the accrual of consumer welfare as well. Thus it is not clear that there were necessarily lost opportunities as a consequence of the court processes that are not also attendant to the regulatory regime. Regulation would be superior only if it was demonstrably faster at resolving disputes than the court process or resulted in a more efficient outcome. Given the extent of welfare gains accrued in the New Zealand case relative to other OECD countries, it is difficult to see how ex ante regulation could have delivered a clearly better static or dynamic efficiency performance in the internet market than exhibited herein.

Concerns were also expressed that the inability of a small entrant to underwrite a lengthy court action might induce Telecom to charge higher prices, thereby limiting the gains achievable from increased competition. If the only option available was action brought by another firm, then this argument might be plausible. However, the Commerce Act provisions allowed the Commerce Commission as the ultimate custodian of the public interest to bring a case if it was deemed necessary due to the degree of fragmentation of the potential claimants (as occurred with '0867'). Again, it is difficult to draw conclusions apart from the observation that in the '0867' case small firms (ISPs) through lobbying the Commission achieved the result of a prosecution without having to incur the full costs themselves. Such 
free-riding might actually result in inefficiently too much being spent on lobbying and litigation in respect of cases ultimately found not to be exertions of dominance.

\subsubsection{Courts, Regulation and Efficiency}

Also to be considered is the observation from Blanchard (1995) and expanded by Carlton \& Picker (2007) and Howell (2007; 2008) is that in the pursuit of efficiency, court-based processes are hampered by the fact that courts are restricted to addressing the matters brought before them. Litigated cases may not be the most important in respect of ensuring the pursuit of efficiency. Furthermore, dependent upon the economic knowledge of the judges or the body of jurisprudence used to decide a matter, an action adjudged to be competitive may actually result in a reduction in efficiency. For example, the acceptance of ECPR in the Clear case imposes a pricing precedent which is not always the most efficient in all circumstances (Economides \& White, 1995). Whilst this statement is true, it is also by no means certain that decisions made by regulators are any better in respect to promoting increased efficiency - for example, when short-run pursuit of competition is prioritised over long-run pursuit of dynamic efficiency (Howell, 2008a).

\subsection{Summary}

In conclusion, therefore, the evidence indicates that on balance, the New Zealand telecommunications sector under the light-handed regulatory regime combining predominantly competition law and contractual constraints performed more efficiently than the average OECD country in respect of both static and dynamic efficiency gains, whilst the net gains and losses from the transaction costs of the institutional regime are somewhat equivocal.

\section{Industry-Specific Regulation: 2002-2007}

Following the 1999 general election, in 2000 the incoming coalition government instigated a Ministerial Inquiry into Telecommunications ${ }^{20}$. Despite undertaking an analysis of prices and uptake of services, and finding New Zealand's performance not dissimilar to other OECD countries, the Inquiry recommended the replacement of the competition law-governed regime with an industry-specific regulator with the power to set prices for a range of PSTN-related services (termed 'designated' services). The justification given was that cost benefit analyses indicated Telecom was still charging prices in excess of cost, thereby necessitating regulatory

${ }^{20}$ http://www.med.govt.nz/templates/StandardSummary 16318.aspx 
intervention and the imposition of TSLRIC-based prices (i.e. the industry should be regulated because it was not performing according to the benchmark of theoretical perfect competition, rather than because it was performing demonstrably less well than regimes operating under the type of industry-specific regulation proposed).

Importantly, however, the inquiry exempted data services from becoming designated, requiring instead that they be wholesaled by Telecom to competitors at regulated 'retail minus' prices. Local loop unbundling (LLU) was also rejected on the basis that substantial investment in facilities-based competition had already occurred, but with the proviso that a further inquiry be undertaken into its feasibility before the end of 2003 (Section 64). These recommendations were accepted and given legal force in the Telecommunications Act 2001. Importantly, the Act contained a section 19(2) requiring that the Commissioner take account of economic efficiency when making his determinations and recommendations, but granted the Minister the power to reject recommendations made by the Commissioner in respect of additional services to be regulated (Howell, 2008b).

The further recommendation that Telecom alone should bear the cost of the 'Kiwi Share' social obligations until such time as it could justify to the Minister that its losses necessitated adjustments to its capped retail prices was rejected and replaced in the Act with the Telecommunications Service Order (TSO). Under the TSO, the costs to Telecom of maintaining unprofitable 'Kiwi Share' services would be assessed annually by the regulator and shared across all providers in the industry whose trading activities affected Telecom's ability to subsidise the loss-causing customers. The TSO arrangement finally resolved that the entire industry, and not Telecom shareholders alone, bore responsibility for the costs of social obligations, via a mechanism that enabled their costs to be transparently separated from the prices charged by Telecom to its competitor-customers.

The arrangements finally enacted consisted of many political compromises. Industry-specific regulation replaced competition law as the main institutional governance arrangement. Initial hopes were that the new arrangements would address the principal perceived shortcomings of the previous institutions - namely the long time taken to get court decisions and the uncertainty this created, and the degree of contention surrounding interconnection agreements - whilst retaining the benefits of the 'light-handed' approach that had led to the consumer gains accrued across the 1990s. Indeed, the Inquiry report presaged that its recommendations "would still see New Zealand at very much the light-handed end of the spectrum, arguably the lightest in the OECD” ( $\mathrm{p} 30$ ). The workload anticipated for the proposed regulatory authority was presumed to require an annual budget of $\$ 1.5$ million and eight to ten staff (p 28). 


\subsection{Transaction Costs, Institutional Incentives and Dynamic Efficiency}

The Telecommunications Commission was established within the Commerce Commission, and the first Commissioner began duties in March $2002^{21}$. The decision-making process replicated the previous court arrangements, with bilateral agreements between Telecom and its rivals to be mediated by the Commission only if the parties could not come to a satisfactory agreement themselves. Draft determinations, followed by conferences and final decisions once all views had been sought, replicated the court processes of hearing and appeal, but the Commissioner was given wider scope to consider issues not specifically brought by industry participants.

\subsubsection{Few Incentives to Negotiate}

In practice, however, the structure of the Commission processes and the provisions of the Act removed all incentives for market participants to strike contracts outside of the regulatory process. As the costs of the Commission were funded by a market share-based levy on all participants, small participants could seek their own determinations rather than relying upon the precedents set by the larger firms (as occurred following the 1991-94 Clear case) - in effect, free-riding on the larger contributions towards the costs of the processes made by the larger participants. Furthermore, the Act precluded any party striking a product access agreement with Telecom outside of the regulatory process from subsequently petitioning the regulator for a determination in respect of that product. Specifically, if another party later was granted regulated access to the same product at more favourable terms, the first firm could not seek a regulatory intervention to gain access on the same terms as the regulated agreement.

The consequence was virtually every agreement between Telecom and its rivals was brought before the Commission. This sharply contrasted with only two contested contracts in the twelve preceding years, and the extensive use of the Clear-Telecom agreement as a benchmark for other contracts. In 2003, decisions were sought by each of TelstraClear, iHug, CallPlus. Compass and WorldXChange for both interconnection and wholesale access to Telecom's other services. However, given the quasi-court process to be followed, decisions were not made rapidly. The first decision, requested in May 2002, was decided in draft form in November of that year and not made final until May 2003, backdated to June 2002. Moreover, determinations were initially made for one year periods. Applications for

\footnotetext{
${ }^{21}$ http://www.beehive.govt.nz/Print/PrintDocument.aspx?DocumentID=12604
} 
determinations relating to subsequent years were being lodged within days of final decisions being announced for agreements relating to current years.

Simultaneously, the new Commission was also tasked with making the first TSO determinations, and by the end of 2003 undertaking a full Inquiry into the efficacy of local loop unbundling. Not surprisingly, the under-resourced Commission rapidly came under pressure given the large and substantially unanticipated workload it faced. Even though budgets were expanded (by the 2004/5 financial year, expenditure exceeded $\$ 3.7$ million $^{22}$ ), the time taken to reach decisions dragged out. The first TSO determination, for the 6 month period 21 December 2001 to 30 June 2002, begun in March 2002, was delivered on December 18, $2003^{23}$. The second determination, for the period 1 July 2002 to 30 June 2003, was not finalised until 24 March 2005. The third TSO determination, for the 2003/4 year, was finally announced on March 26, 2007 $7^{24}$. The 2004/5 and 2005/6 determinations were jointly announced on July $92007^{25}$, by which stage a review of the entire TSO arrangement, led by the Ministry of Economic Development, was in process ${ }^{26}$. In a similar vein, the mobile termination inquiry begun in April 2004 was not finally resolved until April 2007 - longer than it took for the 1990s 'Clear' case to go through three court hearings.

The process shortcomings were in part addressed by amendments in 2006 allowing standard terms determinations as a means of reducing the work volume. That this step was considered necessary appears a clear admission that relative to the pre-2001 arrangements, the post-2001 institutional arrangements substantially increased the transaction costs of system operation, irrespective of the quality of the decisions made.

\subsubsection{The TSO and Dynamic Efficiency Consequences}

The longer times taken to make decisions reduced dynamic efficiency gains in the market relative to the 1987-2001 period. Whereas previously firms could trade whilst court cases were disputed, under the Commission processes, no new services were offered by Telecom's competitors until the respective contracts had been brokered by the Commission. This inevitably led to delays in benefits to consumers from any product differentiation or lower prices potentially offered by competitors and new entrants.

\footnotetext{
${ }^{22}$ Commerce Commission Annual Report 2004/5 p 24.

${ }^{23}$ http://www.comcom.govt.nz/IndustryRegulation/Telecommunications/telecommunicationsactcommercecommi.aspx

${ }^{24}$ http://www.comcom.govt.nz/IndustryRegulation/Telecommunications/telecommunicationsactcommercecommi5.aspx

${ }^{25}$ http://www.comcom.govt.nz/IndustryRegulation/Telecommunications/telecommunicationsactcommercecommi6.aspx

${ }_{26}$ http://www.beehive.govt.nz/ViewDocument.aspx?DocumentID=30366
} 
An especial concern attends the delays incurred in settling the TSO levies. The TSO is essentially a 'tax' on entrants to compensate Telecom for revenues foregone in those areas where by dint of the prices Telecom was charging above cost to subsidise rural consumers competitive entry was disproportionately concentrated due to the distortion in retail prices. In theory, the tax would overcome the problem of more entry than efficient occurring in highly competitive areas by passing on the costs of social services to entrants. In effect, Telecom had already been doing this pre-2001, by using ECPR to set interconnection prices. However, under regulated TSLRIC prices, where the costs could not be included in Telecom's prices to competitors, the compensation had to be recovered via alternative mechanisms.

Whilst the TSO process made the cost to each entrant explicit and transparent, the time taken to reach a determination added substantial additional uncertainty to entry and pricing decisions. As the TSO levy was determined in arrears - up to three years after the trading activity had occurred - it became impossible to make reasonable entry and pricing decisions with any realistic confidence. Each party had to assess not just the effect of its own strategies upon the market, but also those of all its competitors to forecast likely the future tax liability. The more participants in the market, the harder the tax forecasting task became. Even small errors in assumptions could have significant ramifications upon break-even and entry decisions - a significant barrier for small new entrants who lacked reserves to bear the risks of possible underestimations, the extent of which would be discovered only when the tax was finally levied. Entry was therefore substantially discouraged, relative to the case where Telecom's ECPR price indicated prior to the entry or pricing decision what the extent of the liability would be.

It is also noted that retention of universal service pricing via the TSO perpetuated the perversion of investment incentives in rural areas. Whereas it is likely that alternative technologies (e.g. wireless and mobile) offered lower-cost solutions in many rural areas, Telecom's obligation to subsidise rural connections both made it uneconomic for more efficient alternative investments to occur whilst simultaneously requiring capital expenditure to be outlaid in maintaining and upgrading a likely less efficient network.

\subsubsection{Effect of Industry-Specific Regulation on Market Structure}

Hence, it is unsurprising that, unlike the 1990s, no new entry occurred in the fixed line sector between 2001 and 2007. Rather, the dominant structural changes occurring were mergers between existing firms with a market presence prior to 2001, notably the horizontal integration occurring as network companies bought each other (e.g. TelstraClear formed from Telstra, Clear and Saturn) and vertical integration as network operators bought ISPs (e.g. 
Kordia (fibre, satellite, microwave, wireless and backhaul) buying Orcon, Woosh (wireless) buying Quicksilver and Vodafone (mobile) buying iHug). Each merger reduced both competition in the market and the risks posed to decision-making as a consequence of the TSO process. Moreover, the mergers increased both the ability of the small firms to bear the TSO forecasting risks and improved the quality of information available upon which to base pricing and entry decisions (mobile provider Vodafone was subject to TSO charges as a consequence of the competitive effects of mobile upon the fixed line connection and calling market).

Furthermore, granting other firms regulated wholesale access to Telecom's data services had substantial effects upon the willingness of firms to continue investing in their own networks, even though they had been willing investors in differentiated networks under the pre-2001 regime. The TelstraClear CEO welcomed the first wholesale determination in November 2002 thus: "we believe its more industry efficient for TelstraClear to buy from Telecom rather than build duplicate networks to reach consumers who are widely spread throughout New Zealand”27. TelstraClear had previously suspended rollout of its fibre-optic cable network ${ }^{28}$, not long after launching in Christchurch, its third geographic region, in July $2001^{29}$. It is noted that at the 2000 Inquiry, TelstraClear's predecessor company Telstra Saturn had advocated strongly against LLU because open access to Telecom's infrastructure would undermine the case for ongoing investment in its own fibre-optic network.

\subsection{Static Efficiency Performance}

The impression of the intensely vibrant, competitive interaction during the 1990s, with substantial welfare gains being accrued by consumers as market participants sought to strategically out-manoeuvre each other on the basis of contracts and commercial engagement coming to a grinding halt in the 2000s under industry-specific regulation is borne out by the New Zealand residential price index in Figure 6, and the Telecommunications Consumer Price Index in Figure 7.

\subsubsection{Regulated Rates and Price Indices}

Following the extensive gains made in the 1990s (Figure 1), both the fixed line rental and the long distance call indices flattened (Figure 6) following regulation, a pattern that remains in place through to 2007 in the Services component of the CPI index (in contrast to the

\footnotetext{
${ }^{27}$ http://www.telstraclear.co.nz/companyinfo/media_release_detail.cfm?newsid=81\&news_type=tclArchive

${ }^{28}$ http://www.wordworx.co.nz/TelecomsReviewBBandCity.htm

${ }_{29}$ http://www.med.govt.nz/templates/MultipageDocumentPage $\quad$ 4850.aspx\#P324 40851
} 
continually declining Equipment component - Figure 7). Whilst the OECD time series 'Total' also shows evidence of flattening over the 2000s (Figure 2), unlike the New Zealand index, calling charges continued to decline. The New Zealand performance must also be assessed in conjunction with the 2000 inquiry analysis that there were still presumed to be significant 'rents on the table' for Telecom that justified setting regulated TSLRIC prices for fixed line voice services..

The first regulated interconnection agreement in 2002 fixed a TSLRIC-benchmarked price of 1.13c per minute, compared to the 2c price in the 1996 agreement (bearing in mind that the 1996 price included a component to cover the Kiwi Share whereas the 2002 price did not). There is no evidence in Figure 5 of any reduction in the interconnection price filtering through as benefits to consumers during 2002 and 2003. Either the rents were not there in the first place (i.e. the ECPR prices compensated only for the social costs subsequently returned to Telecom via the TSO taxes - net of the costs of collecting them, meaning a net decrease in efficiency), or regulated interconnection has resulted simply in a transfer of surplus from Telecom to its competitors (a reallocation of rents). Unlike the 1990s, consumers do not appear to have benefited from lower telephone connection and usage prices. Whilst it is plausible that the gains have been accrued in increased service and product differentiation, in the fixed line voice calling market there is little real differentiation between providers in services offered. Rather, Figures 5 and 6 can be interpreted as symptomatic of a static market with few changes occurring, consistent with the introduction of regulatory delays and/or strict adherence to historic pricing patterns as providers facing considerable new uncertainties adopt a risk-averse stance.

An examination of prices in the broadband market also confirms relatively static patterns of interaction. The Telecommunications index in Figure 6 includes internet connection and utilisation prices. The low prices for ADSL originally introduced by Telecom in 1999 have remained largely unchanged in nominal terms albeit with increases in service quality as more capable DSLAMs were installed (not captured in the index). Telecom began entering into wholesale agreements with competitors in 2003 to provide wholesale services as fast as the DSLAM allowed. By 2006, these were offered to all competitors. The base 2Mbps service has now been upgraded to $8 \mathrm{Mbps}$ in most areas, and as high as 20Mbps in some urban locations. There has clearly been an increase in consumer welfare from increased uptake of the new and faster technologies. However, given the extent to which New Zealand broadband uptake lags international comparators, the apparently lower welfare gains in this market despite lower prices requires further analysis. Aside from the more generally-accepted factors depressing New Zealand's uptake (low GDP per capita, low population density, low 
urbanisation - de Ridder, 2007; Wallsten, 2006), the institutional regulatory governance arrangements and ensuing strategic interactions between market participants, the regulator and government also offer some credible explanations.

\subsubsection{Bitstream Unbundling, Broadband Uptake and Market Structure}

Bitstream unbundling was mandated in December 2003, but not introduced until September 2004. Figure 8 shows that over the first three quarters of 2004, whilst the growth rate of ADSL connections was accelerating, the market share Telecom's competitors fell from over $35 \%$ to less than $24 \%$. It cannot be discounted that in anticipation of the bitstream products becoming available, competitors had few incentives to sell the existing wholesale products despite their affiliated ISPs commanding around $50 \%$ of the now-mature dial-up internet market (Figure 4). That is, mandating bitstream access regulation resulted in a temporary reduction in competition given the time required to introduce a new regulated service. The data are consistent with the 'regulatory delay' theory postulated in section 3.1 above.

However, Figure 8 reveals that, even after bitstream services were made available, the market share sold by competitors hovered consistently around $25 \%$ for over a year in a rapidly growing market where the competitors already had a commercial relationship with at least half of the most likely purchasers - the dial-up ISP customers. A likely explanation is that given Telecom's already low prices and the extensive range of two-part tariffs offered, there was no margin available in the bitstream product market upon which competitors could arbitrage. Howell (2003) shows that at the time, even New Zealand broadband consumers buying connections with high data caps (10Gb/month) typically consumed only low volumes of data (average 1.5Gb/month; median $800 \mathrm{~kb} / \mathrm{month}$ ). Consumers could pick the most appropriate access and data bundle in order to minimise monthly cash outlay, meaning entry level packages with low data caps were the most popular for substituting dial-up users. When the Commission calculated TSLRIC-benchmarked cost-based prices for the bitstream services they indicated monthly prices higher than the entry level retail prices charged by Telecom since 1999 (Covec, 2004). The Commissioner reverted to retail-minus pricing for this service, but even so, the regulated wholesale price of $\$ 27.76$ ultimately decided ${ }^{30}$ compared to $^{2}$ the entry level Telecom retail price of only \$29.95 per month.

\footnotetext{
${ }^{30}$ Draft price $\$ 28.04$ replaced by $\$ 27.76$ in the final report.

http://www.comcom.govt.nz/IndustryRegulation/Telecommunications/ihugandcallpluswillhavebitstreamac.aspx http://www.comcom.govt.nz/IndustryRegulation/Telecommunications/commissionapprovesupdatedpriceforw.aspx .
} 


\subsubsection{Strategic Responses to Regulatory Incentives}

Whilst Telecom's competitors predictably claimed Telecom's prices to be evidence of overt predatory pricing behaviour designed to foreclose competition, the fact that these prices had prevailed for over 5 years without any anti-trust cases being brought and were matched over this period by other providers of broadband on other technologies makes this claim difficult to substantiate. However, the competitive response not to vigorously pursue the burgeoning broadband market at this time was predictable on two counts.

Firstly, as the margins competitors received from selling dial-up internet access accounts exceeded the margins available from bitstream ADSL, it was not in their interests to actively promote the substitution of their higher revenue-generating dial-up customers to the less profitable bitstream broadband products. Secondly, the bitstream access arrangement regulated in lieu of full LLU in 2003 was conditional upon Telecom selling both an agreed number of ADSL connections $(250,000)$ by the end of 2005, with at least one third of them being sold by competitors. Telecom was put on notice that if these targets were not reached, the government would impose more stringent regulatory provisions. For competitors wishing to gain access to unbundled copper loops instead of investing in their own networks (predominantly the ISPs selling dial-up connections), it was not in their interests for Telecom to succeed in meeting the targets. Strategic gaming of the uptake statistics by refraining from actively marketing ADSL would yield both higher margins in the short run, and likely a more favourable set of regulated access arrangements in the long run.

Thus, the market dynamics illustrated in Figure 8 are plausibly explained by competitive responses to actual and threatened regulatory intervention. Likewise, New Zealand's sluggish uptake of broadband is plausibly explained by a combination of the Kiwi Share making dial-up a very cheap alternative, and the strategic interaction in the sector resulting from the cumulative effects of the market dynamics established by the combination of the interconnection contracts and Kiwi Share obligations applying in the 1990s overlaid by the effects of regulatory intervention in the 2000s. That New Zealanders did not start purchasing broadband in large numbers until 2004 despite very low prices prevailing is most likely explained not by exertion of market power or other impediments to competition but by simple welfare economics.

\subsubsection{Demand-Side Responses Reflected in Usage and Revenue Data}

Until new applications unable to operate successfully on dial-up came into widespread use, for low volume users (the majority of New Zealanders) free dial-up access offered better net value (welfare) than broadband that had to be paid for (Howell, 2008; 2008b). The rise in 
New Zealand's broadband connections parallels almost exactly the rise in membership of the country's most-visited web property, the consumer-to-consumer trading portal TradeMe (transaction volumes on this site rose from nothing in 2004 to an average of over 1000 page views per month per active New Zealand internet account in 2008 - the period in which New Zealand has exhibited one of the fastest broadband connection growth rates per capita in the OECD (Howell, 2008b). This has also been when worldwide growth in use of peer-to-peer sites such as YouTube, Bebo, Facebook and Skype has become significant. New Zealanders’ substitution to broadband has simply occurred later than in other countries where the telephony component of dial-up internet access was charged, as the marginal valuation of internet use at which substitution will occur is lower the greater the extent to which dial-up usage is subsidised from connection charging (Howell, 2008).

The cumulative effect of the growth of broadband connections is reflected in the comparative revenue index in Figure 9. Whilst OECD revenues grew steadily compared to 1997 levels over the period 1997 to 2005, New Zealand revenues did not exceed 1997 levels until 2002, at which point, consistent with the growth in broadband accounts, revenues began growing. Whereas in the average OECD country, consumers paid for use of the internet incrementally as their usage grew, in New Zealand it was only once the welfare derived by consumers from broadband use overcame the hurdle imposed by the gifting of free use of dial-up internet have producer revenues been able to 'catch up', with the extent of consumer welfare accrued. It is noted that the area under both the revenue curves in Figure 9 is approximately the same. The difference is that accrual of benefits by producers has been effectively delayed in the New Zealand case by the effect of the 'Kiwi Share' skewing the initial allocation of the welfare benefits of internet use disproportionately towards consumers.

\subsection{Further Efficiency Consequences: LLU and Separation}

Despite an absence of evidence via prices or availability of poor efficiency-related broadband market performance that could not be plausibly explained as consequences of regulatory intervention in the form of either the 'Kiwi Share' or the institutional design of regulatory arrangements post 2001, in May 2006 the Government imposed mandatory LLU. In April 2007 functional separation of Telecom, presaged in the 2006 legislation, was invoked.

The primary justification given for mandating LLU was that New Zealand's broadband uptake per capita was not high enough (i.e. not in the top quartile of the OECD) due to an insufficiently competitive market (Network Strategies, 2006). Even though Telecom exceeded the 2003 target of broadband connections sold at the end of 2005 by $11 \%$ (i.e. 
efficiency had increased to the point that targets were exceeded, if connections are a proxy for the accrual of consumer welfare), as only $25 \%$ were sold by Telecom's competitors, the market was deemed to be insufficiently competitive. Furthermore as Telecom had slipped from investment targets agreed at the 2003 LLU inquiry, it was further proposed that there was an investment 'problem' that on the basis of interviews with Telecom's competitors would be addressed by competitor investment if LLU and separation proceeded (MED, 2006).

Functional separation was proposed as a means of creating transparency, 'levelling the playing field' between Telecom and its competitors, further incentivsing investment in the New Zealand industry and thereby assisting with the achievement of broadband uptake targets (MED, 2006).

\subsubsection{Dynamic Efficiency and Investment Incentives}

The literature on the effects of LLU on sector investment suggests that the policy may either stimulate investment by new entrants via the 'Ladder of Investment' or chill investment incentives for the incumbent (Hausman \& Sidak, 2005). The New Zealand evidence above suggests that regulatory intervention already undertaken had led to a chilling of investment by entrants in their own platforms, even though Telecom appeared to have prioritised its own investment towards new services (i.e. ADSL). In 2003, Telecom announced that it had entered into an agreement with Alcatel to develop what would have been at the time the OECD’s first nationwide Internet Protocol-based Next Generation Network (NGN). The Commissioner's decision not to recommend full LLU in 2003 and instead to mandate bitstream unbundling was in part predicated upon the risks to continued Telecom investment in that project if LLU proceeded, and the risk that given the imminent NGN deployment, the assets of unbundling entrants would rapidly become stranded as exchange bypass occurred (Commission, 2003; Covec, 2004). That is, LLU was rejected on longer-term dynamic efficiency grounds under Section 19(2) of the Telecommunications Act.

The LLU decision has had a profound effect upon Telecom's investment incentives. The small size of the New Zealand economy and the large cost of investing in the NGN or any other fibre-based network means there are few firms with the resources to engage in such a project, from both the extent of capital required or the ability to underwrite the large risks inherent. Telecom is the largest firm (it has comprised of between $20 \%$ and $25 \%$ of the capitalisation of the New Zealand exchange for its entire listing life) in a market for sector investment which is very thin. If Telecom does not invest in new networks, it begs the question of who else will. The investment incentives facing Telecom thus take on a different 
national economic dimension to those in other countries where capital markets are more robust.

\subsubsection{Investment and Revenues}

For any investment to proceed, firms must be able to receive a fair return on that investment to compensate for both capital use and risk. The 2006 Stocktake (MED, 2006) found that Telecom's overall investment levels were less than in other comparator countries on a per capita basis and on the basis of investment as a percentage of revenue. Whilst Figure 10 appears to confirm that New Zealand's investment as a share of revenue fell substantially from 2002, separate analysis of revenues and investment in Figure 9 indicates that in the post2002 period, New Zealand's investment indexed to 1997 levels has exceeded the OECD average.

The reason for the fall-off in Figure 10 is because New Zealand's revenues have increased post-2002 as (finally) consumers are paying positive prices for broadband internet access whereas historically they were subsidised to use dial-up internet access. Moreover, New Zealand's investment levels began tracking upward at the same time as revenues began increasing. Quite simply, investments require returns. The slippage in Telecom's NGN investment plans could plausibly be explained by the fact that the firm underestimated the effect of dial-up internet subsidies on the delay and suppression of broadband substitution rates and therefore its ability to invest as extensively in the NGN and as early as it had originally planned. When revenues began accruing, investment accelerated. Further, it cannot be discounted that additional regulatory obligations (e.g. bitstream unbundling provision) diverted investment and workforce attention otherwise intended for the NGN.

Figure 10 also confirms that, unlike the rest of the OECD, where investment increased dramatically in the dot-com boom and then plummeted in the 2001 crash and had only just returned to 1997 levels by 2005, the New Zealand industry patterns remained constant. Consequently, the inefficient over-investment and extensive stranding of assets occurring in many other OECD markets following the crash were not significant features of the New Zealand market.

\subsubsection{Investment Compromises, Higher Costs and Stranded Assets}

However, following the LLU and separation decisions, Telecom's NGN investment incentives have altered markedly. The costs of the new regulations were quickly factored into the market price for Telecom shares, which are currently trading at $\$ 3.28$, their lowest price in 
15 years $^{31}$. The shares dropped 25\% in value when LLU was announced in May $2006^{32}$. They have dropped a further $20 \%$ in value in the two years subsequently, as the full ramifications of the regulatory regime upon Telecom have become apparent. It is far from clear (and most unlikely) that this reduction in Telecom shareholder value has been captured as share value increases recorded in other firms in the market (many are not listed).

In response to the LLU and separation policies, in April 2007 Telecom management announced that of the $\$ 1500$ million needed to build the network envisaged in the government's policy, under the current arrangements, it could justify only $\$ 500$ million. The threat to withhold investment was made credible in May 2007, when the company returned $\$ 1,100$ million of the proceeds of the sale of its directory business to shareholders ${ }^{33}$.

Following extensive negotiations, however, the firm announced on October 26 that it would proceed with an investment of $\$ 1,400$ million over the next five years, with a view to all towns with more than 500 lines being able to receive next-generation IP-based network services and ADSL services of $20 \mathrm{Mbps}$ by $2012^{34}$. Whilst this announcement appears to reinstate the 2003 NGN plan objectives, as a result of the falling share price and the unequivocally higher cost of capital this imposes, the network will cost substantially more than under the pre-LLU and separation counterfactual. These increases will inevitably be passed through to consumers, especially if as a consequence of regulatory changes, investment in competing networks is further chilled and Telecom's dominance in the provision of broadband services is increased due to even greater reliance upon its networks to provide last-mile connections to consumers.

Perversely, Telecom's NGN investment decision leading to increased dynamic efficiency from better services renders the decisions by competitors to proceed with investments in Telecom's exchanges under LLU vulnerable to losses, and the market to increased static inefficiencies, as a consequence of asset stranding (as presaged by the Commissioner in 2003). Thus, it is not surprising to find Telecom's competitors accusing the firm of being anticompetitive, and seeking regulatory intervention to protect them from the consequences of Telecom's decisions to close exchanges already subject to unbundling as it replaces them with kerbside NGN cabinets. Not surprisingly, Telecom has prioritised its investments around the same high volume, low cost exchanges which have attracted the most competitor interest -

\footnotetext{
${ }^{31}$ http://www.nzx.com/news/markets/4607445

${ }_{32}$ Wilkinson (2006) estimates the LLU decision resulted in the write-off of \$3 and \$4 billion of shareholder value - close to the price paid for the firm on privatization in 1990.

${ }^{33} \mathrm{http}: / /$ www.telecom.co.nz/binarys/q3_07_presentation.pdf, p 3

${ }^{34}$ http://www.telecom-media.co.nz/releases detail.asp?id=3497\&page=1\&pagesize $=10$
} 
not because of the motive of foreclosing competition but because these are the ones where it is economically most rational to invest as the potential returns are higher. Interestingly, the most prolific investor in Telecom's unbundled exchanges (and the owner of the largest stock of likely stranded assets) is the government-owned Kordia-Orcon.

\subsubsection{The Scale of New Zealand and the Impact of Regulatory Overheads}

In addition to the dynamic incentive effects, further transaction costs have been imposed on the industry as a consequence of proceeding with LLU and separation. Both are very costly processes, and must be considered in proportion to the small scale of the New Zealand market and the likely extent of any additional benefits, given prices are already low and ADSL speeds high by OECD standards. Functional separation was estimated by Telecom to impose a fixed cost of NZ\$300 million on the firm - not dissimilar to the $£ 70$ million estimated fixed cost to BT of creating Openreach (converted using purchasing power parity exchange rates). The effect of scale suggests that the per capita or per account costs of separation will be very much larger in New Zealand than in Britain, indicating a much higher benefit threshold must be passed to justify the adoption of separation in New Zealand. On the basis of household size, the costs per household of the fixed costs alone are 16 to 17 times higher in New Zealand than in Britain. Had a comparative cost-benefit analysis been undertaken, the benefits of separation would have needed to be 16 to 17 times greater per household than those in Britain to justify proceeding.

Benchmarking the costs of separation against the costs of a broadband account suggests that it is highly unlikely that the fixed costs of separation are likely to be recouped in further benefits. Even using generous estimates based upon New Zealand meeting its Digital Strategy target of entering the top quartile of the OECD in broadband connections per capita (i.e. approximately the 25 connections per 100 or 1 million broadband accounts) indicates a fixed cost of separation of $\$ 300$ per broadband account. This burden equates to the cost of 10 months broadband access based upon the entry level product. The ongoing costs equate to a further $10 \%$ of the monthly costs equated on a per-account basis. Apportioned across the 650,000 accounts already purchased at the time separation was announced (a less generous allocation), the policy imposed a per-account burden equivalent to between 16 and 17 months connection.

It is difficult to see where benefits of the extent indicated will be generated as a consequence of the regulatory instrument chosen being implemented. Inevitably, Telecom's prices must rise if these costs are to be recovered and the firm is to remain financially viable. 


\subsection{Summary}

In sum, therefore, it would appear that the industry-specific regulatory regime from 2002 to 2007 has failed to generate efficiency gains comparable to the regime that preceded it. As a consequence of the incentives created and substantial underestimation of their effects, the institutional arrangements imposed are more bureaucratic and cumbersome, and hence more costly in both out-of-pocket expenses and potential dynamic efficiency losses than the arrangements that proceeded them. Neither is it clear that they have succeeded in making the market more competitive. Indeed, the reverse appears to have occurred, with strategic gaming of political and regulatory processes appearing to replace strategic competitive commercial interaction in shaping the direction of the industry. Whilst investment is occurring, it is more costly than previously was the case as a consequence of the additional overheads incurred.

\section{Lessons from New Zealand}

Returning to the questions posed in Section 1, on balance over the efficiency metrics chosen for analysis, it can be concluded that the competition law-based regime prevailing in New Zealand between 1987 and 2001 outperformed the comparator 'OECD average', where industry-specific regulation of the form New Zealand subsequently adopted prevailed. In all of the dimensions of static and dynamic efficiency and institutional transaction costs examined, the 2002-7 regime performance was incrementally worse than the 1987-2001 regime. Consequently, it can be concluded that, in the New Zealand case, the industryspecific regulatory regime has failed to improve on overall sector efficiency performance relative to the regime it replaced. The failure has led to further changes increasing the degree of regulatory restraint, which are unlikely to result in further improvements.

However, it is too simplistic to take the analysis as 'proof' that competition law offers a superior governance method. The New Zealand example illustrates that the contracts and agreements that shape the interaction between participants, whether they be commerciallynegotiated or imposed by governments or regulatory institutional design, are the fundamental determinants of sector performance. Issues of institutional design have been significant at the margin, especially in respect of the costs imposed by New Zealand's Commerce Commission processes pre-2006, which are not necessarily features of regulatory process design in other countries (e.g. Finland - Howell \& Sangekar, 2008). Their effects cannot be ignored. However, the consequences of the 'Kiwi Share' have been the most influential factors in determining relative and absolute performance of the sector. 
'Kiwi Share' consequences shaped interaction in the 1990s, spurred the Clear case, created the burgeoning growth of internet use and the consequent strategic arbitrage that seeded both dynamic efficiency improvements and the subsequent '0867' case. Historic decisions made in the 1990s therefore affected the types of strategic interaction occurring in the 2000s. Low ADSL prices meant the New Zealand market responded differently to opening up access to bitstream unbundling than in other countries. Subsidised dial-up internet access distorted consumer responses to broadband products. New Zealand's market responded differently from other OECD markets.

Unfortunately, it was all too easy for the New Zealand politicians, public, regulators and market participants pre-2001 to jump to the flawed conclusion that it was the differences in overarching industry governance arrangements and institutions that were 'causing' the observable differences. The flaws in reasoning that led to increasingly more stringent industry-specific regulation were driven in part by over-reliance upon structural and institutional measures of competitiveness in assessing sector performance - e.g. market shares and the number of entrants - and insufficient attention being given to efficiency-related measures such as prices and revenues. The focus on institutions and market structure rather than contracts and efficiency further obscured the need to revisit the one part of the regulatory arrangements that was not assigned to the purview of either the courts or the regulator - the 'Kiwi Share'.

The lessons to be taken from the analysis of the New Zealand industry are that in the final analysis, it is the nature of the contracts and participants' responses to them that matter most for sector performance. Optimal institutional arrangements will differ depending upon underlying economic circumstances and the nature of contractual interaction that ensues. Competition law and industry-specific regulation are complements which can in conjunction lead to increased efficiency, as shown under the joint governance of competition law and the 'Kiwi Share' in the 1990s. They do not have to be seen only as substitutes (Crandall \& Picker, 2007). The removal of the purview of a regulator from the day-to-day governance of the sector does not mean the end of regulatory control, if contractual undertakings and legislated obligations can impose comparable disciplines that further the pursuit of economic efficiency. In the final analysis, the balance must be determined by trading off the different forms of efficiency consequences of each set of circumstances as they are faced. There is no 'one size' of regulation, institution, competition or market structure that 'fits all'. Each case must be measured and assessed on its efficiency-based merits and underlying economic circumstances. Pursuit of efficiency, not pursuit of competition, must be the goal. 


\section{References}

Alleman, J. \& Rappoport, P. (2005). Regulatory failure: time for a new paradigm. Communications and Strategies 60 pp105-121.

Arnold, T., Boles de Boer, D., \& Evans, L. (2003). The structure of industry in New Zealand: its implications for competition law. In Berry, M. \& Evans, L. (Eds) Competition law at the turn of the century. Wellington, New Zealand: Victoria University Press.

Blanchard, C. (1995). Telecommunications regulation in New Zealand: light-handed regulation and the Privy Council's judgement. Telecommunications Policy 19(6), 456-75.

Blanchard, C. (1994a). Telecommunications regulation in New Zealand: the Court of Appeal's decision in Clear Communications $\mathrm{v}$ Telecom Corporation. Telecommunications Policy 18(9), 725-33.

Blanchard, C. (1994b). Telecommunications regulation in New Zealand: how effective is 'light-handed' regulation? Telecommunications Policy 18(2), 154-64.

Boles de Boer, D., Enright, C., \& Evans, L. (2000). The performance of Internet Service Provider (ISP) markets of Australia and New Zealand. Info 2(5), 487-95.

Boles de Boer, D., \& Evans, L. (1996). The Economic Efficiency of Telecommunications in a Deregulated Market: the Case of New Zealand. Economic Record, 72(216), 24-39.

Carlton, D., \& Perloff, J. (2005). Modern industrial organization (4 ${ }^{\text {th }}$ ed.). Boston: Pearson/Addison Wesley.

Carlton, D., \& Picker, R. (2007). Antitrust and Regulation. National Bureau of Economic Research Working Paper 12902. Available on http://www.nber.org/papers/w12902.

Commerce Commission. (2003). Telecommunications Act 2001 Section 64 review and schedule 3 investigation into unbundling the local loop network and the fixed public data network Final Report. Wellington, New Zealand. Available on http://www.comcom.govt.nz//IndustryRegulation/Telecommunications/Investigations LLocalLoopUnbundling/ContentFiles/Documents/finalreport.PDF .

Covec (2004). Benchmarking Telecom's UPC service. Available on http://www.comcom.govt.nz//IndustryRegulation/Telecommunications/Investigations /Unbundling-

PartialCircuits/ContentFiles/Documents/Final\%20Draft\%20Report\%20(August\%204 \%202004)\%20-\%20UPC\%20Benchmarking.pdf).PDF .

De Ridder, J. (2007). Catching-up in broadband - what will it take? Working Party on Communication Infrastructures and Services Policy paper DSTI/ICCP/CISP(2007)8/FINAL, OECD, Paris. Available on http://www.oecd.org .

Economides, N., \& White, L. (1995). Access and interconnection pricing? How efficient is the "efficient component pricing rule"? Antitrust Bulletin 40(3), 557-79.

Enright, C. (2000). Strategic Behaviour of Internet Service Providers in New Zealand and the Performance of this Market. Wellington, New Zealand: New Zealand Institute for the Study of Competition and Regulation. Available on http://www.iscr.org.nz/navigation/research.html .

Evans, L., Grimes, A., Wilkinson, B., \& Teece, D. (1996). Economic reforms in New Zealand 1984-1995: the pursuit of efficiency. Journal of Economic Literature 34 (December 1996), 1856-1902.

Evans, L., \& Quigley, N., (2000). Contracting, incentives for breach and the impact of competition law. World Competition 23(2).

Ford, G., Koutsky, T., \& Spiwak, L. (2007). Competition after unbundling: entry, industry structure and convergence. Federal Communications Law Journal 59, 331-68.

Guthrie, G. (2006). Regulating infrastructure: the impact on risk and investment. Journal of Economic Literature 44(4), 925-972.

Hausman, J., \& Sidak, G. (2007). Evaluating market power using competitive benchmark prices instead of the Herfindahl-Hirschman Index. Antitrust Law Journal 74(2): 387407. 
Hausman, J., \& Sidak, G. (2005). Did mandatory unbundling achieve its purpose? Empirical evidence from five countries. Journal of Competition Law and Economics 1(1), 173245.

Howell, B. (2008). Competition, regulation and broadband diffusion: the case of New Zealand. In Dwivedi, Y., Papazafeirapoulu, A., \& Choudrie, J. (Eds) Handbook of research on global diffusion of broadband data transmission New York: Information Science Reference.

Howell, B. (2008a). The end or the means? The pursuit of competition in regulated telecommunications markets. Paper presented at the International Telecommunications Society $17^{\text {th }}$ Biennial Conference, Montreal, Canada, June 25, 2008.

Howell, B. (2008b). Regulated retail tariff structures, dial-up substitution and broadband diffusion: learning from New Zealand's experience. Paper presented to the European Association of Researchers in Industrial Economics (EARIE) conference, September 4-6, 2008, Toulouse, France.

Howell, B. (2007). A pendulous progression: New Zealand's telecommunications regulation 1987-2007. Wellington, New Zealand: New Zealand Institute for the Study of Competition and Regulation. Available on http://www.iscr.org.nz/f378,10548/10548_Pendulous_Progress_v_4_12_Nov.pdf

Howell, B. (2006). Submission: Telecommunications Amendment Bill. Available from http://www.iscr.org.nz.

Howell, B., \& Sangekar, M., (2008), Telecommunications market evolution in Finland and New Zealand: unbundling the differences. Wellington, New Zealand: New Zealand Institute for the Study of Competition and Regulation. Available on http://www.iscr.org.nz/f436,12631/12631_Market_Evolutions_BH_080708.pdf

Howell, B., \& Marriott, L. (2004). The state of e-commerce in New Zealand. In Poot, J. (Ed.) On the edge of the global economy (pp.287-381) Cheltenham UK: Edward Elgar.

Howell, B., \& Obren, M. (2003). Telecommunications usage in New Zealand: 1993-2003. Wellington, New Zealand: New Zealand Institute for the Study of Competition and Regulation. Available on http://www.iscr.org.nz/navigation/research.html .

Howell, B. (2003). Building best practice broadband: bringing infrastructure supply and demand together. Wellington, New Zealand: New Zealand Institute for the Study of Competition and Regulation.

Available on http://www.iscr.org.nz/navigation/research.html .

Karel, A. (2003). The development and implications of free ISPs in New Zealand. Wellington, New Zealand: New Zealand Institute for the Study of Competition and Regulation. Available on http://www.iscr.org.nz/navigation/research.html .

Laffont, J-J., \& Tirole, J. (2002). Competition in teleccommunicatons. MIT Press, Cambridge, Massachusetts.

Lim, E., \& Chen, Z. (2008). Measuring barriers to trade in telecommunications. Paper presented at the International Telecommunications Society $17^{\text {th }}$ Biennial Conference, Montreal, Canada, June 25, 2008.

McTigue, M. 1998. Alternative to regulation: a study of reform in New Zealand. Regulation 21(1), 34-40.

Melody, W., (2005), Regulation and network investment: a framework for analysis. Chapter 1 in Mahan, A., \& Melody, W. (eds) Stimulating Investment in Network Development: Roles for Regulators pp 19-38. Lyngby, Denmark: WDR Project, LIRNE.NET.

Ministry of Commerce \& The Treasury. (1995). Regulation of access to vertically-integrated natural monopolies. Wellington, New Zealand: Ministry of Commerce; The Treasury.http://www.med.govt.nz/templates/MultipageDocumentPage 4560.aspx

Ministry of Economic Development. (2006). Promoting competition in the market for broadband services. Wellington, New Zealand: Ministry of Economic Development. Available on http://www.med.govt.nz/upload/36537/promoting-competition.pdf . 
Network Strategies. (2006). The broadband divide: achieving a competitive international ranking. Wellington, New Zealand: Ministry of Economic Development. Available on http://www.med.govt.nz/upload/36790/broadband-divide.pdf.

New Zealand Institute of Economic Research. (2005). Telecommunications pricing in New Zealand: a comparison with OECD countries. Wellington, New Zealand: NZIER.

Organization for Economic Co-Operation and Development (2008). Broadband growth and policies in OECD countries. Paris: OECD. Available on http://www.oecd.org .

Organization for Economic Co-Operation and Development (2007). Communications Outlook 2007. Paris: OECD. Available on http://www.oecd.org .

Organization for Economic Co-Operation and Development. (2001). The development of broadband access in OECD countries. Paper DSTI/ICCP/TISP(2001)2/FINAL. Paris: OECD. Available on http://www.oecd.org .

Organization for Economic Co-Operation and Development. (2000). Local access pricing and e-commerce. Paper DSTI/ICCP/TISP(2000)1/FINAL. Paris: OECD. Available on http://www.oecd.org .

Spiller, P., \& Cardilli, C. (1997). The frontier of telecommunications deregulation: small countries leading the pack. Journal of Economic Perspectives 11(4), 127-38.

Wallsten, S. (2006). Broadband and unbundling regulations in OECD countries. Working Paper 06-16, AEI-Brookings Joint Center for Regulatory Studies.

Wilkinson, B. (2006). Restraining the leviathan in telecommunications. Paper presented at the Law and Economics Association of New Zealand, Wellington, 25 September 2006.

Wilson, A. (1994). Wire and wireless: a history of telecommunications in New Zealand, 1860-1987. Palmerston North, New Zealand: Dunmore Press. 
Figure 1. NZ REAL RESIDENTIAL TELEPHONE PRICE INDEX 1991-2001

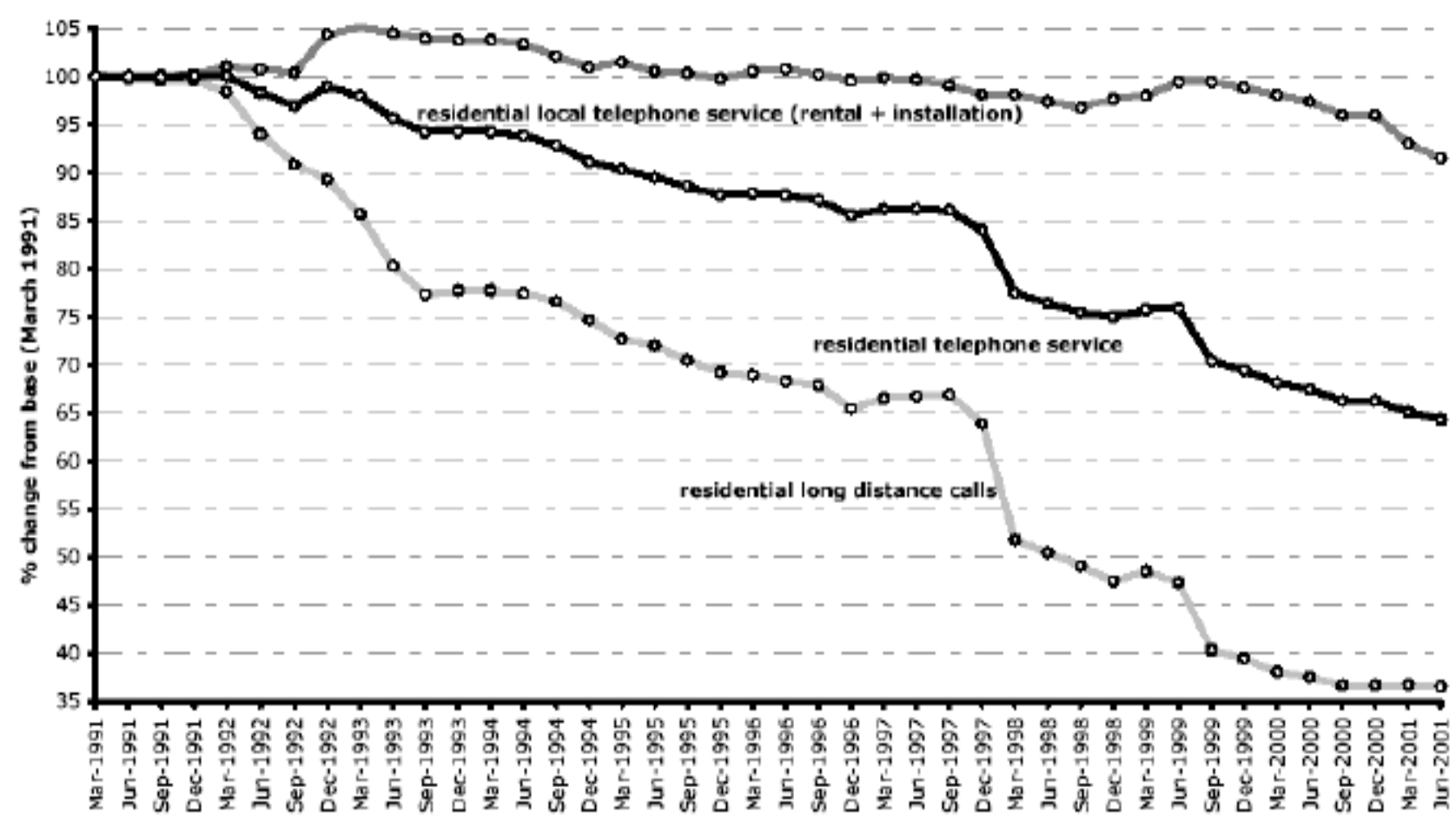

Source: Statistics New Zealand

Figure 2. OECD TELEPHONE CHARGE TIME SERIES 1990-2006

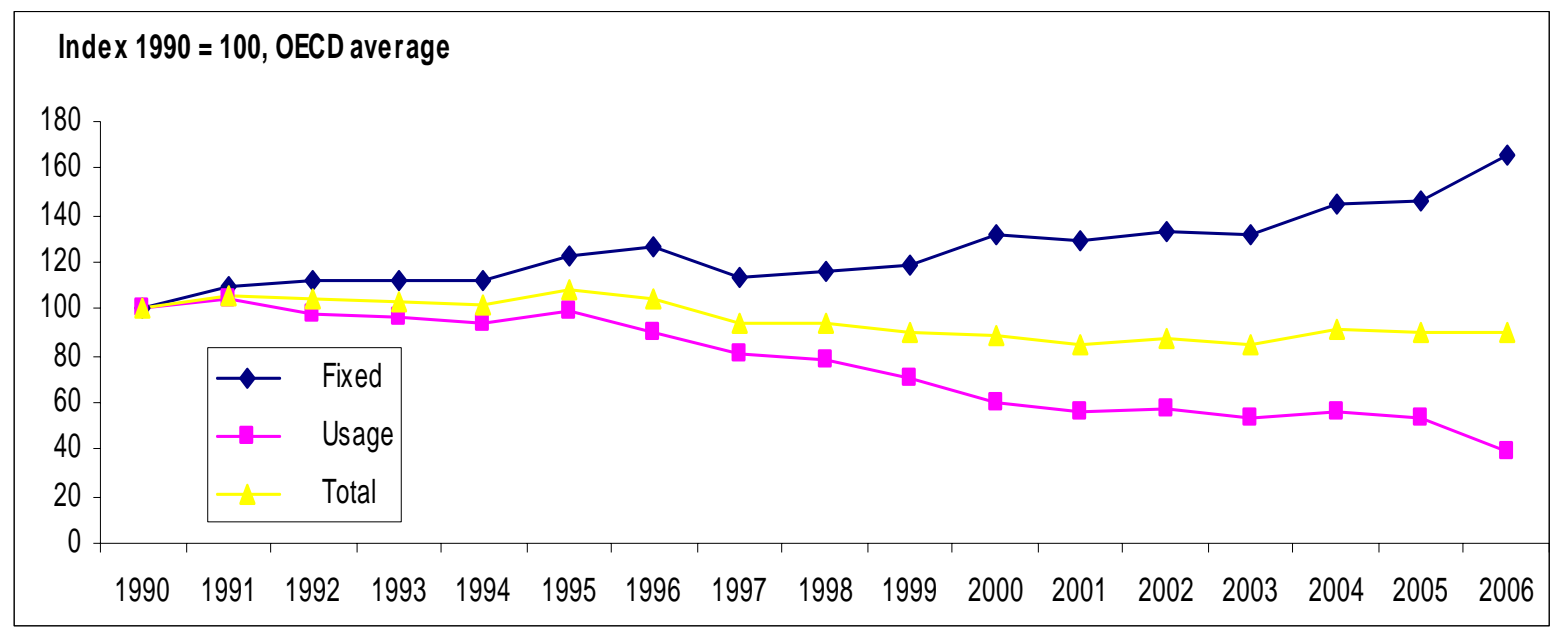

Source: OECD 
Figure 3. New Zealand Telephony Network Traffic 1996-2003

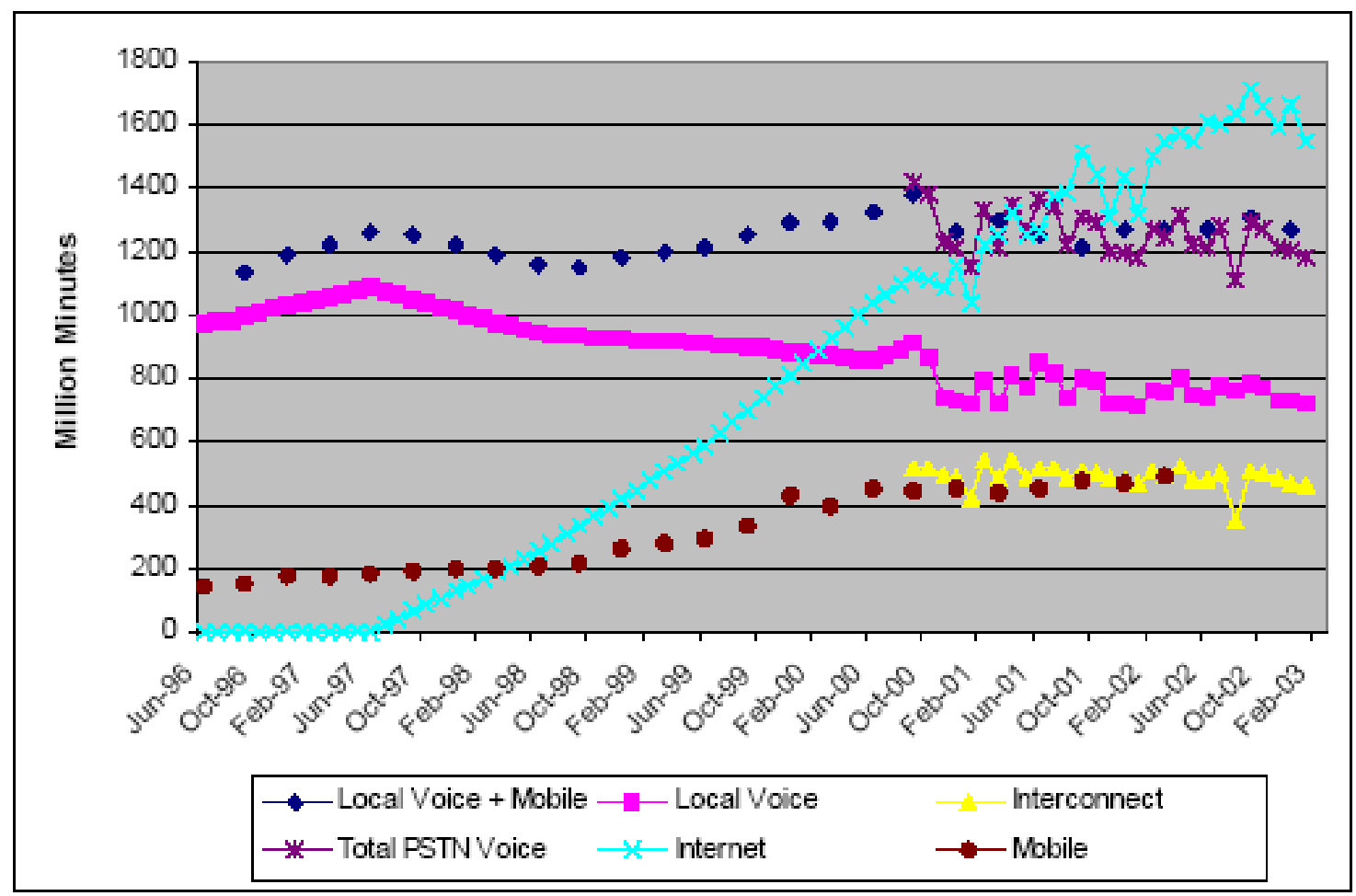

Source: Howell \& Obren (2003:33)

Figure 4

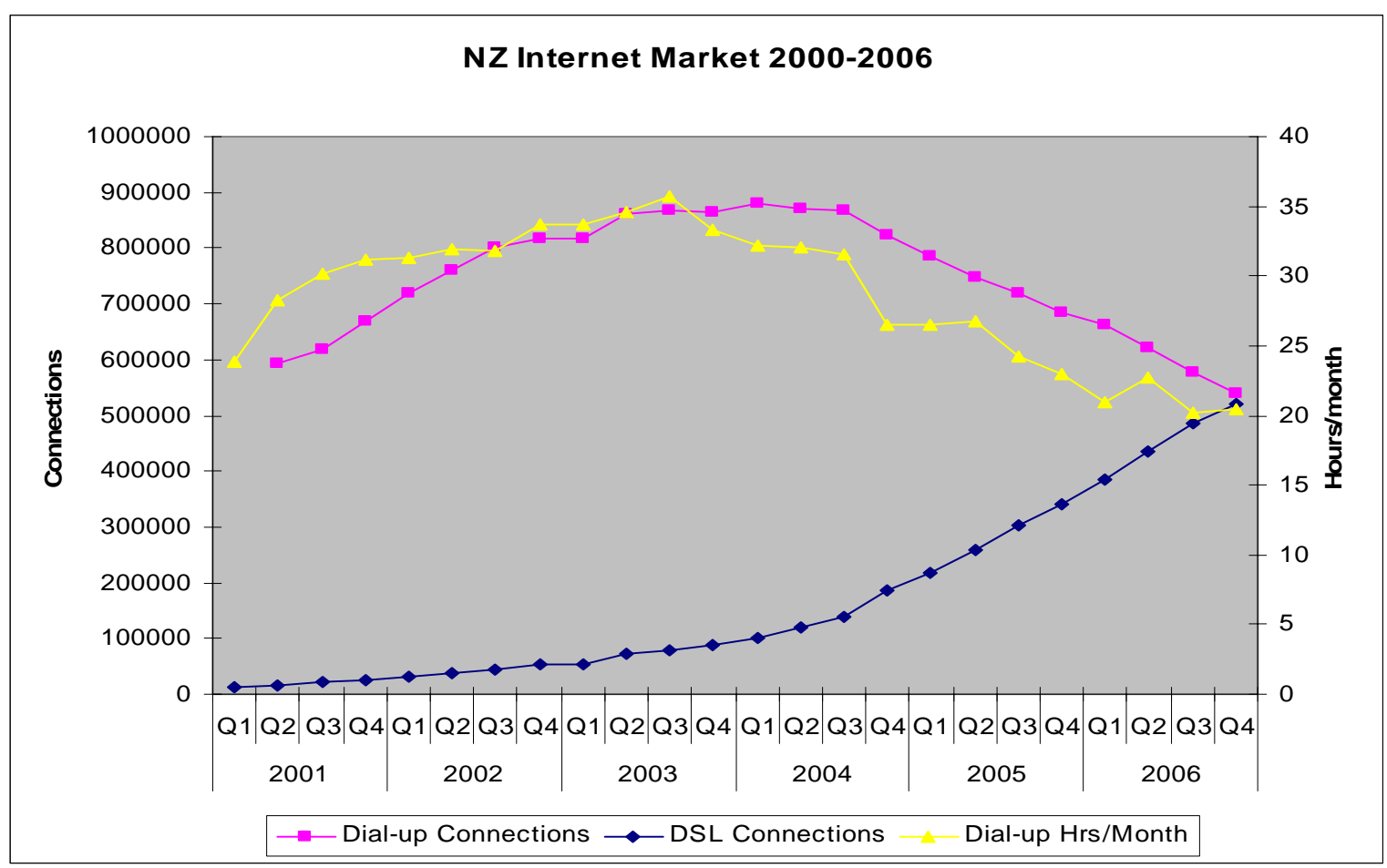

Source data: Statistics New Zealand ISP Surveys and Telecom Management Commentaries 
Figure 5. TELECOMMUNICATIONS REVENUES 1991-2002: OECD, NZ AND SELECTED COUNTRIES

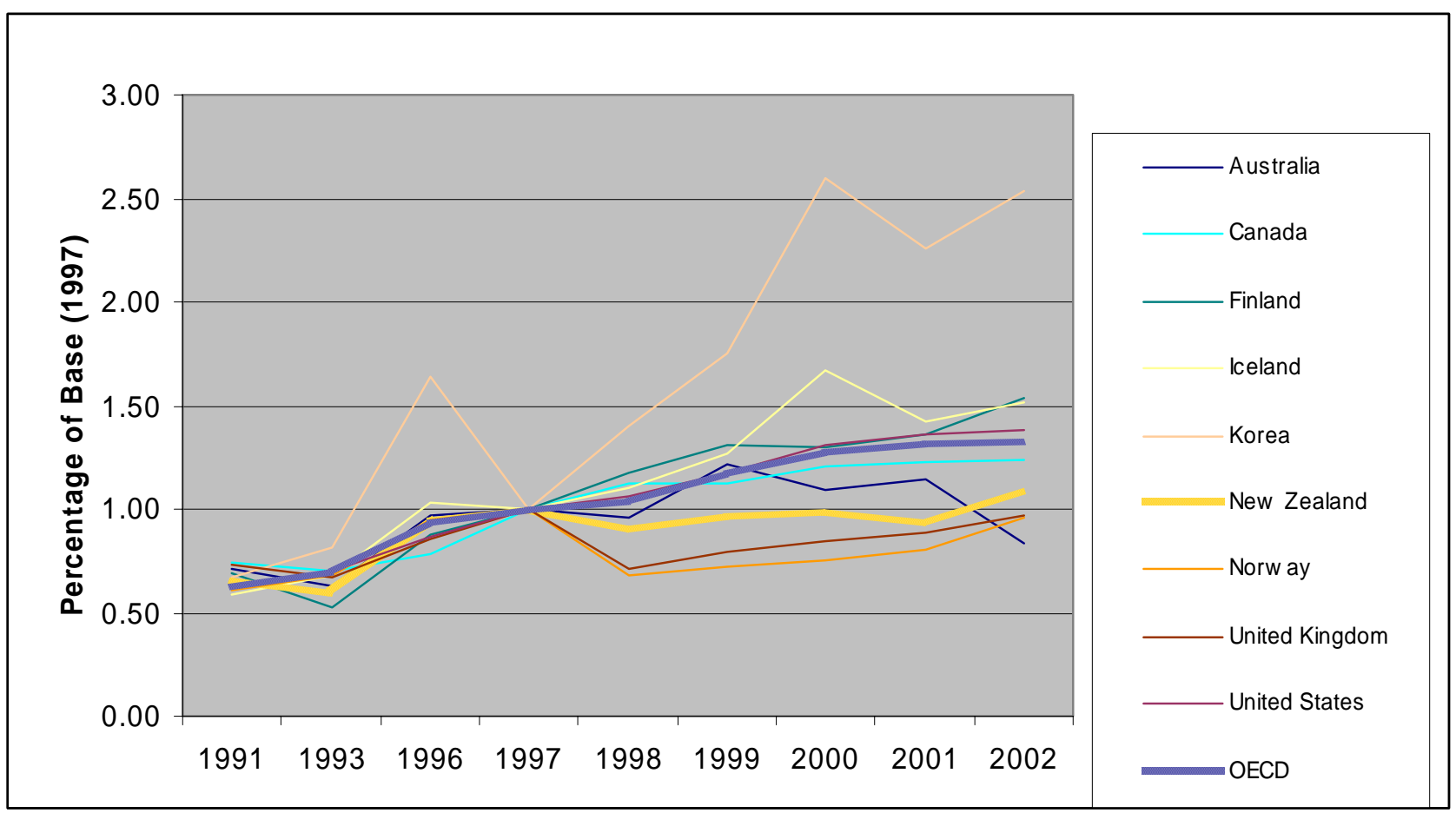

Source data: OECD (2007: 82)

Figure 6

Statistics NZ Real Residential Telephone Service Price Index: March 1991 Base = 100

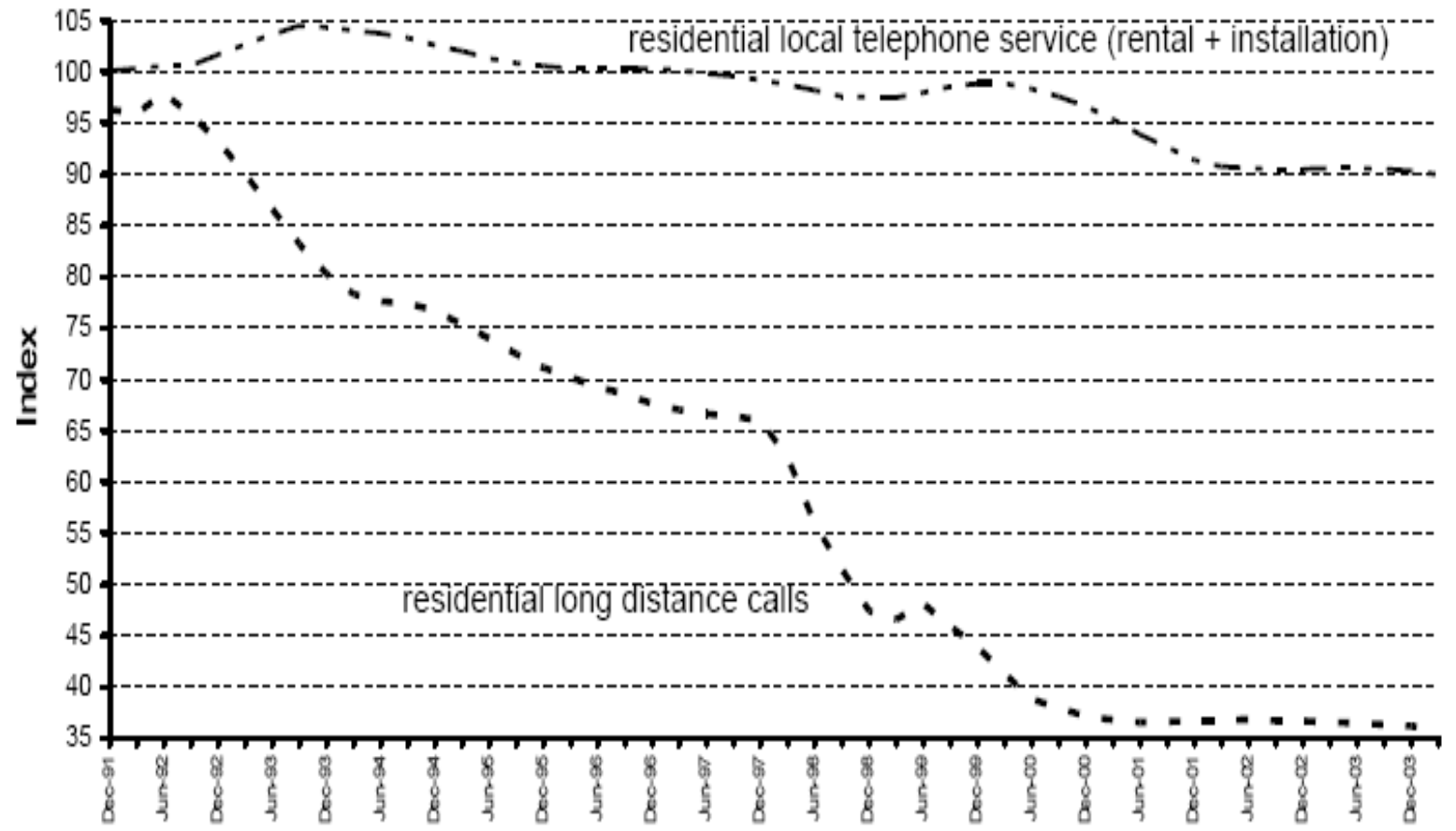

Source: Statistics New Zealand 
Figure 7

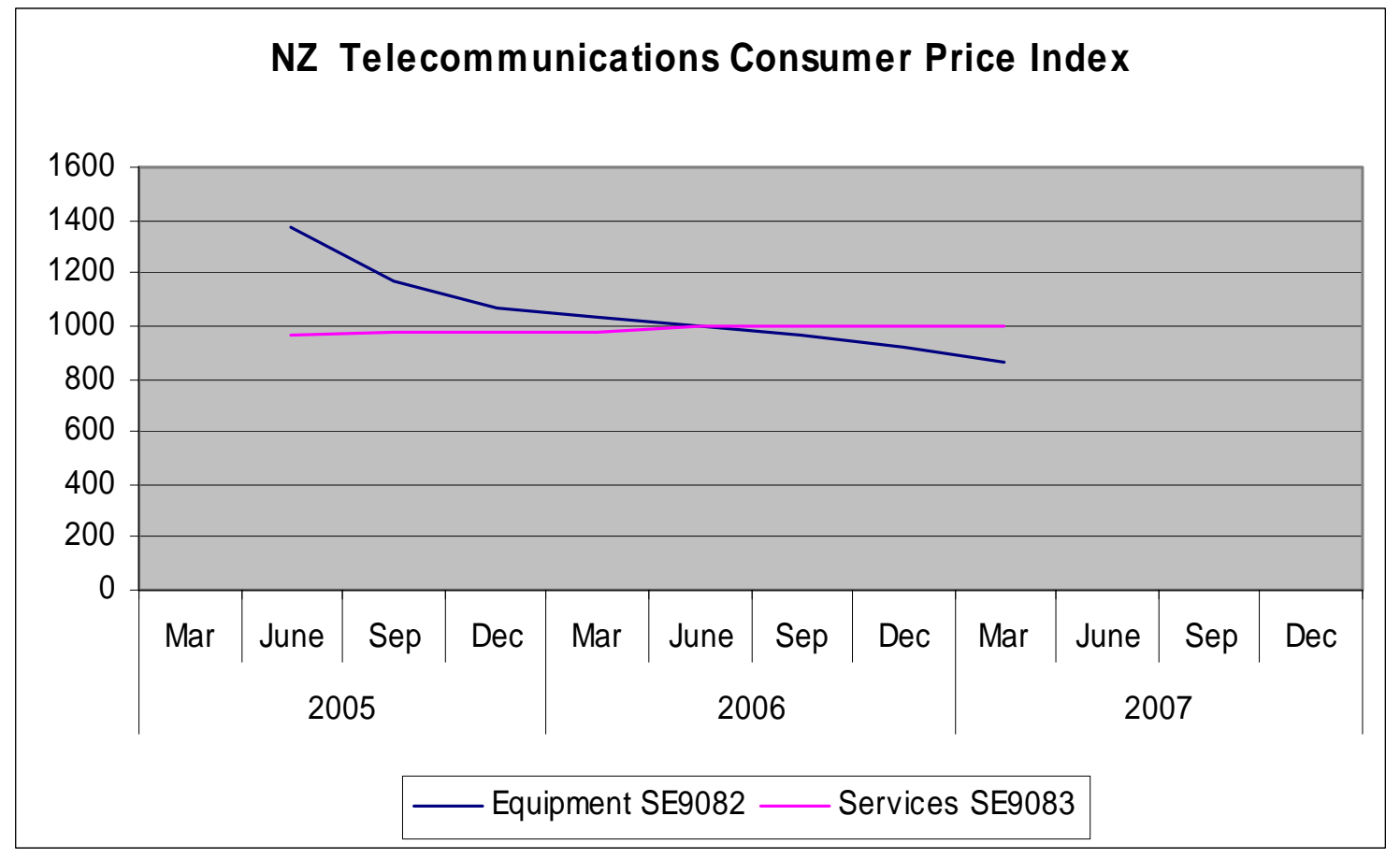

Source data: Statistics New Zealand

\section{Figure 8}

New Zealand ADSL Market 2003-2007

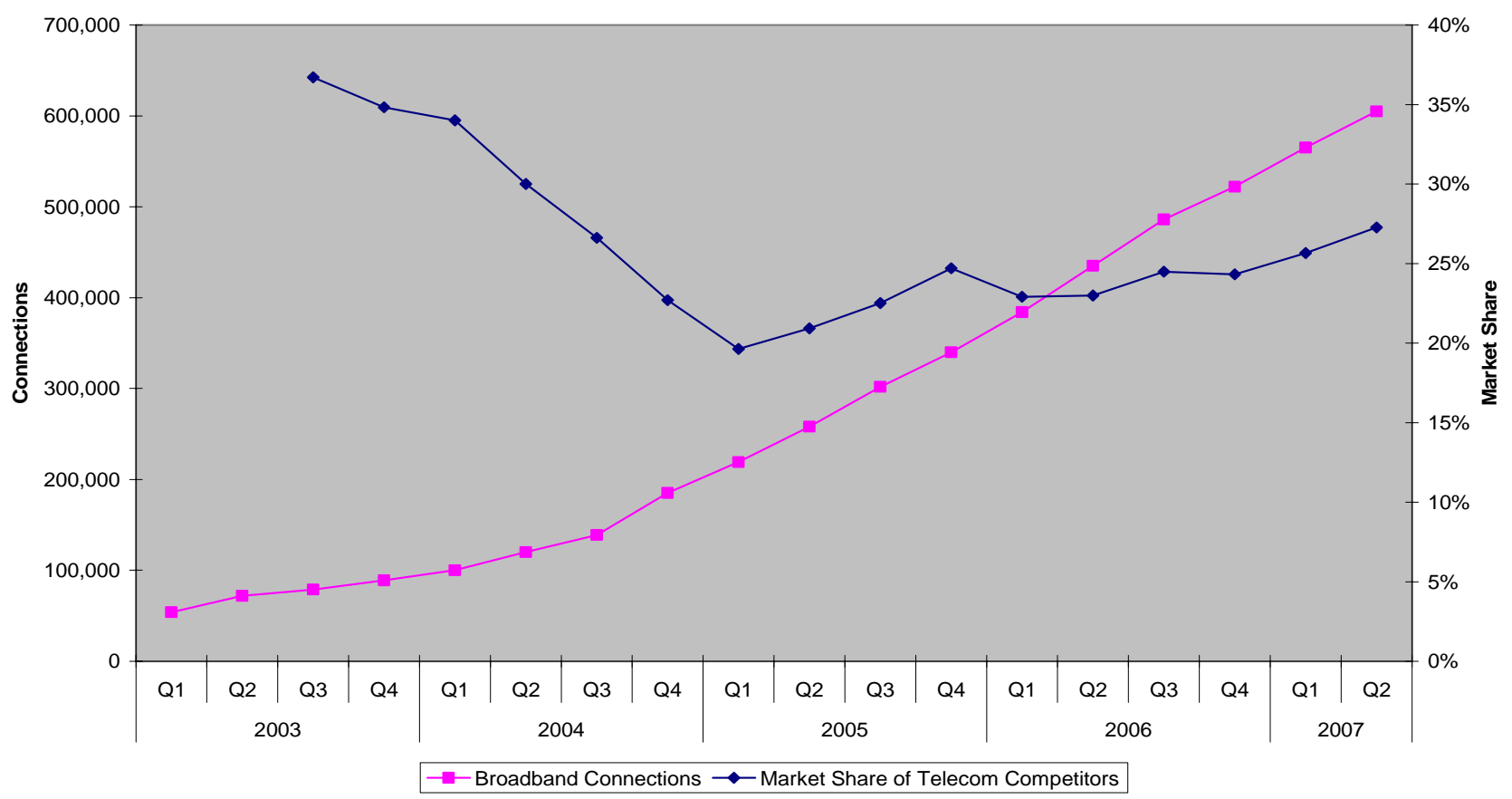

Source data: Telecom Management Commentaries 
Figure 9: Investments and Revenues: NZ and OECD (Index 1997)

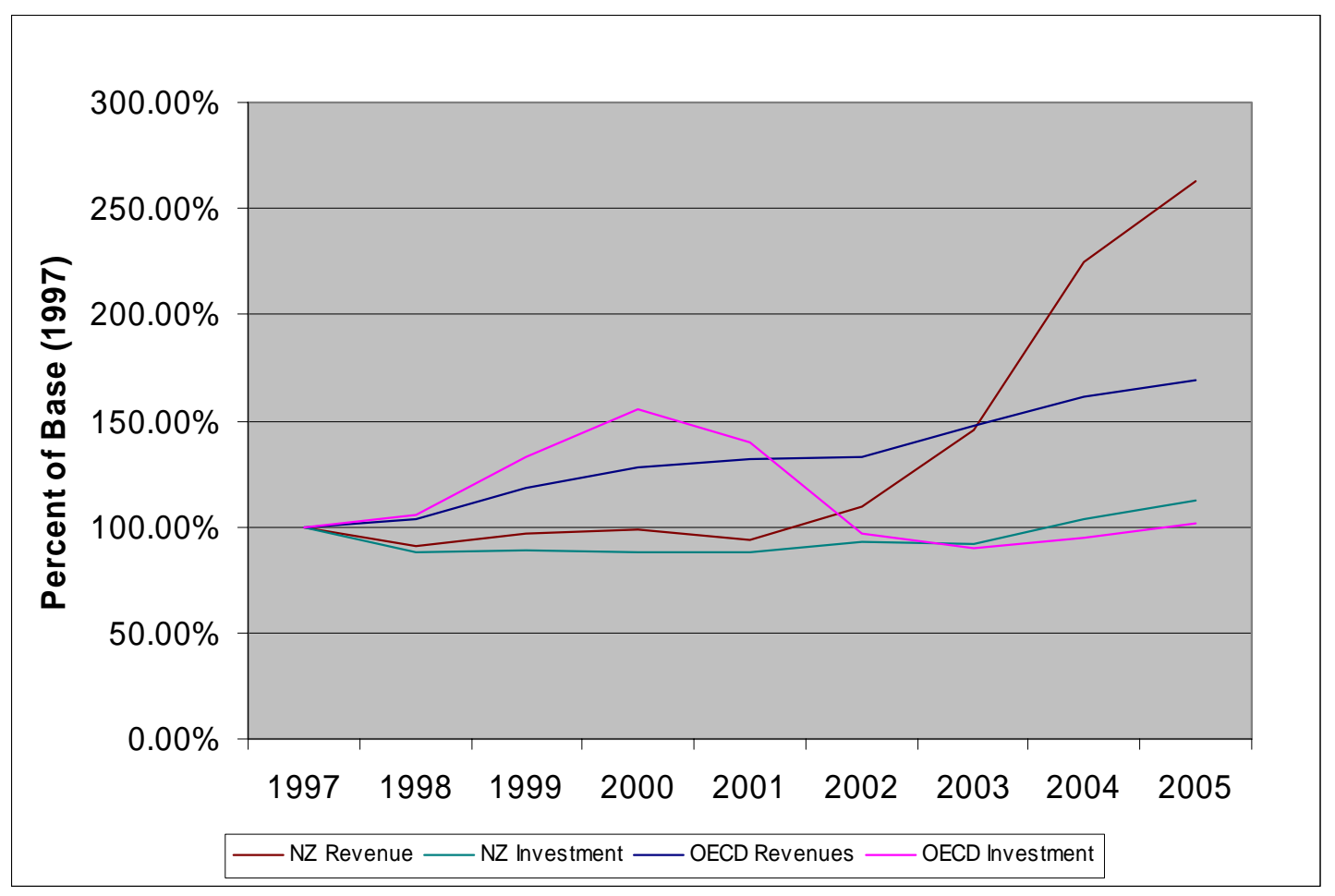

Source data: OECD

Figure 10: Investment as a Percentage of Revenues: NZ and OECD Regions (Index 1997)

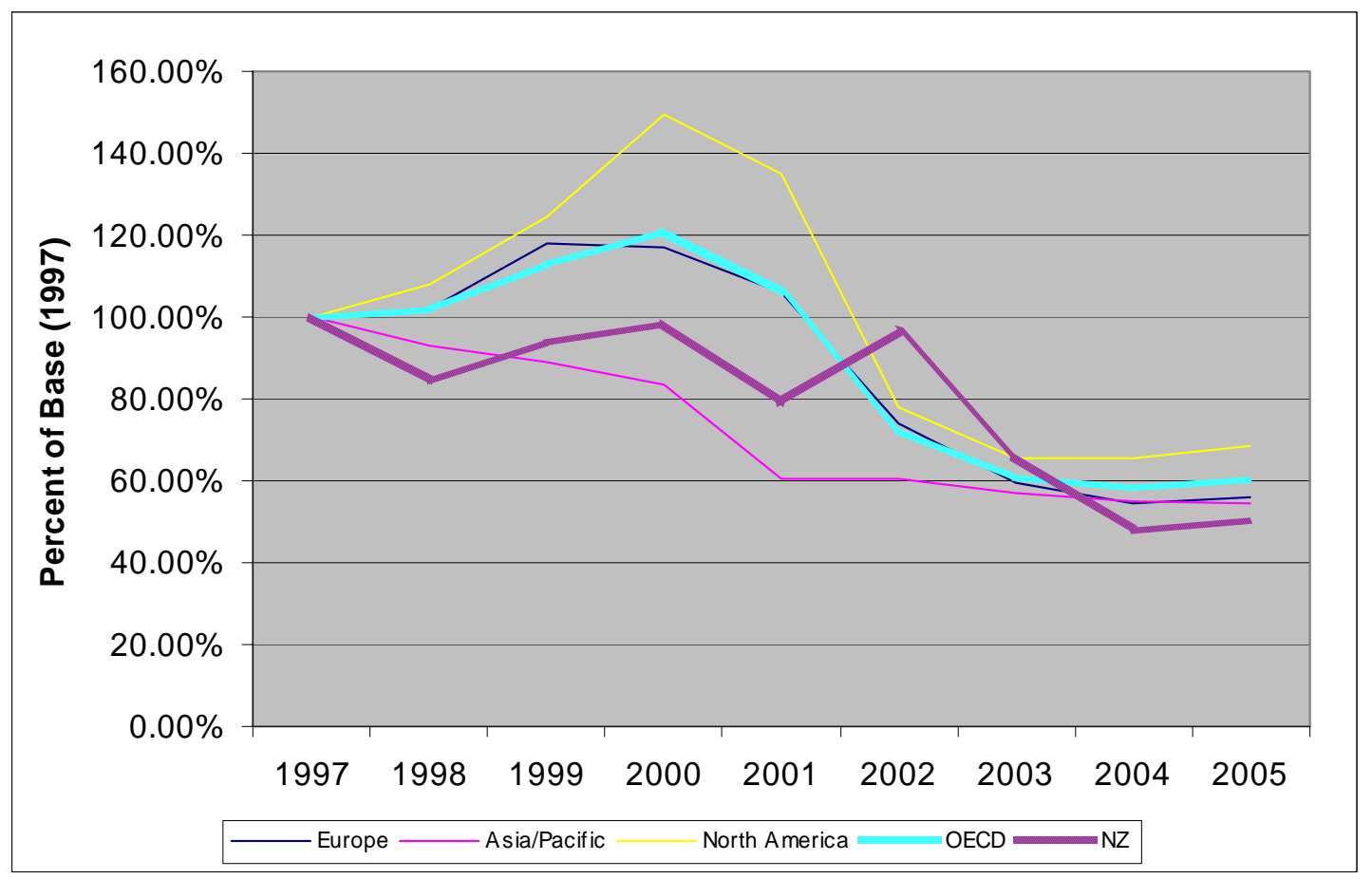

Source data: OECD 